\title{
Effects of conjugated linoleic acid on growth, non-specific immunity, antioxidant capacity, lipid deposition and related gene expression in juvenile large yellow croaker (Larmichthys crocea) fed soyabean oil-based diets
}

\author{
Rantao Zuo, Qinghui Ai*, Kangsen Mai and Wei Xu \\ The Key Laboratory of Mariculture (Ministry of Education of China), Ocean University of China, 5 Yushan Road, \\ Qingdao, Shandong 266003, People's Republic of China \\ (Submitted 7 September 2012 - Final revision received 1 December 2012 - Accepted 14 January 2013 - First published online 4 March 2013)
}

\begin{abstract}
The effects of conjugated linoleic acid (CLA) on growth performance, non-specific immunity, antioxidant capacity, lipid deposition and related gene expression were investigated in the large yellow croaker (Larmichthys crocea). Fish (7.56 (sEm 0.60) g) were fed soyabean oil-based diets with graded levels of CLA $(0,0 \cdot 42,0 \cdot 83,1 \cdot 70 \%)$ for $70 \mathrm{~d}$. Quantitative PCR was used to assess the effects of CLA on the transcription of inflammation- and fatty acid oxidation-related genes. Growth in fish fed the diet with $0.42 \%$ CLA was significantly higher. Also, phagocytic index and respiratory burst activity were significantly higher in fish fed the diets containing $0 \cdot 42$ and $0.83 \%$ CLA, respectively. Hepatic total antioxidative capacity and catalase activities increased significantly when CLA increased from 0 to $0.83 \%$, and then decreased with further increase of CLA. However, hepatic malondialdehyde content decreased significantly as dietary CLA increased. Lipid concentration in the whole body and muscle increased significantly with increasing dietary CLA. Transcription of genes related to inflammation (cyclo-oxygenase- 2 and IL- $\beta$ ) in the liver and kidney and fatty acid oxidation (carnitine palmitoyl transferase I and acyl CoA oxidase) in the kidney decreased significantly as dietary CLA increased. PPAR $\alpha$ and acyl CoA oxidase expression in the liver decreased significantly as CLA increased from 0.42 to $1.70 \%$. These results strongly suggest that dietary CLA could significantly affect growth performance, non-specific immunity, antioxidant capacity, lipid deposition and transcription of inflammation- and fatty acid oxidation-related genes of the large yellow croaker. This may contribute to our understanding of the mechanisms related to the physiological effects of dietary CLA in fish.
\end{abstract}

Key words: Conjugated linoleic acid: Non-specific immunity: Antioxidative capacity: Gene expression

Conjugated linoleic acid (CLA) is a collective term for isomers of linoleic acid $(18: 2 n-6)$ and the two main isomers are cis-9, trans-11 and trans-10, cis-12 $2^{(1)}$. In mammals, CLA has been shown to exert potential health benefits related to its antioxidative, anticarcinogenic, immunomodulative and diabetes-modulator properties in addition to decreasing body fat deposition ${ }^{(2-4)}$. In the last decade, studies have been conducted to investigate the effects of CLA on growth performance, liver lipid deposition, non-specific immunity as well as deposition of this fatty acid in a variety of freshwater fish species including channel catfish (Ictalurus punctatus), tilapia (Oreochromis niloticus), rainbow trout (Oncorbynchus mykiss) and yellow catfish (Pelteobagrus fulvidraco), and some euryhaline fish species, such as sea bass (Dicentrarchus labrax), yellow perch (Perca flavescens) and Atlantic salmon

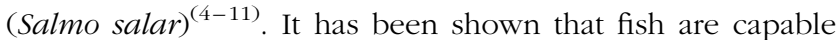
of accumulating high levels of CLA in their tissues when diets are supplemented with this particular fatty acid ${ }^{(12)}$. However, as for growth performance and liver lipid deposition, results vary significantly among different fish species. It has been shown that growth performance is not significantly affected by the inclusion of CLA up to $1 \%$ in juvenile sea bass $^{(4)}$ and Atlantic salmon ${ }^{(10)}$, or $2 \%$ in channel catfish ${ }^{(7)}$. However, growth performance was significantly decreased by CLA at the level of $1 \%$ in hybrid striped bass (Morone saxatilis $\times$ Morone chrysops) $)^{(6)}$ and yellow catfish ${ }^{(11)}$, and by

Abbreviations: ACO, acyl COA oxidase; ARA, arachidonic acid; CAT, catalase; cDNA, complementary DNA; CLA, conjugated linoleic acid; COX-2, cyclo-oxygenase-2; CPT1, carnitine palmitoyl transferase I; HUFA, highly unsaturated fatty acid; MDA, malondialdehyde; PI, phagocytic index; TFA, total fatty acids. 
$2 \%$ in gilthead sea bream (Sparus aurata L.) ${ }^{(1)}$ and tilapia ${ }^{(13)}$. Growth-promoting effects by dietary CLA have also been reported, with weight gain of common carp (Cyprinus carpio) and channel catfish increased by the level of $1 \%$ CLA $^{(14,15)}$. Similar variation has been found in lipid deposition in response to increasing dietary CLA ${ }^{(9-11)}$. Furthermore, little information is available about the effects of dietary CLA on non-specific immunity and antioxidant capacity in fish species $^{(4)}$.

Previously, mechanisms related to the physiological effects of CLA have not been completely elucidated in any animal models. In mammals, dietary CLA can decrease oxidative stress and over-inflammation through suppressing the production of pro-inflammatory cytokines such as IL-2 and TNF- $\alpha$ as well as phospholipid-derived hormones, for example, eicosanoids ${ }^{(16-19)}$. CLA has also been found to exert physiological effects by modulating NF- $\kappa$ B, which controls important cell signalling, phosphorylates certain transcription factors and subsequently activates relevant gene expression $^{(20-22)}$. However, to our knowledge, no information is available about the effects of dietary CLA on the expression of genes related to inflammation and fatty acid oxidation under a formulation with constant $n-3$ highly unsaturated fatty acids (HUFA) and n-3:n-6 PUFA in any fish species. Cyclo-oxygenase-2 (COX-2) is a key biosynthetic enzyme in the synthesis of prostaglandins, such as $\mathrm{PGE}_{2}$. It has been shown that COX-2 is dramatically up-regulated during pathological conditions, such as inflammation and cancer ${ }^{(23)}$. Proinflammatory cytokines, IL- $1 \beta$ and $\mathrm{TNF}-\alpha$, are key regulators of the immune system that shapes innate and adaptive immune responses ${ }^{(24)}$. An adequate balance of the cytokine environment is critical to achieve protective immunity and to avoid immunopathology ${ }^{(24-26)}$.

PPAR $\alpha$, carnitine palmitoyl transferase I (CPT1) and acyl CoA oxidase (ACO) participate in fatty acid oxidation and their expression levels could reflect the oxidative stress inside cells to some extent ${ }^{(27)}$. Previous studies have investigated the relationship between the transcription of these genes and lipid metabolism ${ }^{(1,28)}$. It was shown that transcription of PPAR $\alpha$ could increase in the liver of the large yellow croaker as well as the muscle and adipose tissue of gilthead sea bream as dietary CLA increased from 0 to $4 \%^{(1,28)}$. However, little attention has been paid to the role of fatty acid oxidation-related genes in control of oxidative stress in fish species. Since inflammation, immune function and state of oxidative stress have been found to be closely correlated ${ }^{(29,30)}$, there is great interest to investigate the mRNA expression of fatty acid-related genes ( $P P A R \alpha, C P T 1$ and $A C O)$ in both the liver and kidney of large yellow croaker fed diets with graded levels of CLA.

The large yellow croaker (Larmichthys crocea) is an important marine fish species that is widely cultured in southeast China. During the past few years, studies on the nutrition of this fish have been conducted intensively ${ }^{(31-35)}$. However, as far we know, little information is available about the effects of fatty acid nutrition on immune function, antioxidant capacities and lipid deposition, especially mechanisms involved in these processes for this fish species. Thus, the pre- sent study was conducted to investigate the effects of dietary CLA on growth performance, selected immunological parameters, antioxidant capacity and lipid deposition as well as on the expression of inflammation- and fatty acid oxidationrelated genes in the large yellow croaker.

\section{Materials and methods}

\section{Feed ingredients and diet formulation}

Four isoproteic ( $42 \%$ crude protein) and isolipidic (12\% crude lipid) diets were formulated to contain graded levels of CLA (0, 0.42, 0.83 and $1.70 \%$ dry diet) by adding different amounts of CLA-enriched oil (18:2 cis-9, trans-11: 38.86\% total fatty acids (TFA); $18: 2$ cis-10, trans-12: 32.91\% TFA; Aohai Biotechnology Co., Ltd). Then soyabean oil (China Oil and Foodstuffs Corp.) was added to a final amount of $7 \cdot 0 \%$ oil mixture of dry diet. The optimal $n-3$ HUFA level (about $0 \cdot 8 \%$ dry diet) was guaranteed by supplementing 30\% white fishmeal (crude protein $74.3 \% \mathrm{DM}$, crude lipid 6.6\% DM; Great Seven Biotechnology Co., Ltd) and $2 \cdot 0 \%$ fish oil (arachidonic acid (ARA) content, 0.23\% TFA; EPA content, 13.34\% TFA; DHA content, 10.53\% TFA; Great Seven Biotechnology Co., Ltd) in each diet according to the results of our previous study ${ }^{(36)}$. White fishmeal and soyabean meal (crude protein 49.4\% DM, crude lipid 0.9\% DM; Great Seven Biotechnology Co., Ltd) were included as the main protein sources. Ingredients and nutrient composition of the four experimental diets are given in detail in Tables 1 and 2 .

All ingredients were ground into fine powder so that they passed through a $246 \mu \mathrm{m}$ screen. Ingredients of each diet were blended thoroughly first by hand and then mechanically. The oil mixture was then thoroughly mixed with all ingredients of each diet, after which water $(200 \mathrm{~g} / \mathrm{kg})$ was added to make stiff dough. Pellets $(4 \times 5 \mathrm{~mm}$ and $5 \times 5 \mathrm{~mm})$ were made using an automatic pellet-producing machine (Weihai) and dried for about $12 \mathrm{~h}$ in a ventilated oven at $40^{\circ} \mathrm{C}$. After drying, feeds were packed in double plastic bags and stored at $-20^{\circ} \mathrm{C}$ until used.

\section{Fish rearing and sampling}

Fish rearing and sampling were carried out according to the experimental procedures of the key laboratory of mariculture (Ministry of Education of China), Ocean University of China. Large yellow croaker were bought from a commercial farm in Xiangshan Bay, Ningbo, China. Before the start of the experiment, juveniles were reared in floating sea cages $(3 \times 3 \times 3 \mathrm{~m})$ and fed the control diet for 2 weeks to acclimatise to the experimental conditions and feeds.

At the start of the experiment, the fish were fasted for $24 \mathrm{~h}$ and weighed after being anaesthetised with eugenol (1:10 000) (Shanghai Reagent). Fish of similar sizes (7.56 (sem 0.60) g) were distributed into twelve sea cages $(1 \times 1 \times 1.5 \mathrm{~m})$, and each cage was stocked with sixty fish. Each diet was randomly allocated to triplicate cages of fish. Fish were hand-fed twice daily (05.00 and 17.00 hours) to apparent satiation. The feeding trial lasted for $70 \mathrm{~d}$. During 
Table 1. Formulation and proximate analysis of the experimental diets (\% dry weight)

\begin{tabular}{|c|c|c|c|c|}
\hline & \multicolumn{4}{|c|}{ Dietary CLA level (\%) } \\
\hline & 0 & 0.42 & 0.83 & 1.70 \\
\hline \multicolumn{5}{|l|}{ Ingredients } \\
\hline White fishmeal ${ }^{*}$ & $30 \cdot 00$ & 30.00 & $30 \cdot 00$ & 30.00 \\
\hline Soyabean meal* & $26 \cdot 95$ & 26.95 & $26 \cdot 95$ & 26.95 \\
\hline Wheat meal ${ }^{*}$ & 22.50 & 22.50 & 22.50 & 22.50 \\
\hline Casein* & $5 \cdot 00$ & 5.00 & $5 \cdot 00$ & 5.00 \\
\hline Mineral premix $\dagger$ & 2.00 & 2.00 & 2.00 & $2 \cdot 00$ \\
\hline Vitamin premix $\neq$ & 2.00 & 2.00 & 2.00 & 2.00 \\
\hline Attractant§ & 0.40 & 0.40 & 0.40 & 0.40 \\
\hline Mold inhibitor $\|$ & 0.10 & 0.10 & 0.10 & 0.10 \\
\hline Yttrium oxide & 0.05 & 0.05 & 0.05 & 0.05 \\
\hline Lecithin & 2.00 & 2.00 & 2.00 & 2.00 \\
\hline Fish oilq & 2.00 & 2.00 & 2.00 & 2.00 \\
\hline CLA oil** & 0 & 0.74 & 1.47 & 2.94 \\
\hline Soyabean oiltt & 7.00 & $6 \cdot 26$ & 5.53 & 4.06 \\
\hline \multicolumn{5}{|l|}{ Proximate analysis } \\
\hline Crude protein & $42 \cdot 39$ & 41.89 & $42 \cdot 33$ & $42 \cdot 14$ \\
\hline Crude lipid & $14 \cdot 31$ & 13.86 & $14 \cdot 19$ & 14.20 \\
\hline CLA & 0 & 0.42 & 0.83 & 1.70 \\
\hline
\end{tabular}

CLA, conjugated linoleic acid; TFA, total fatty acids.

${ }^{*}$ White fishmeal: crude protein $74.3 \% \mathrm{DM}$, crude lipid $6.6 \% \mathrm{DM}$; soyabean meal: crude protein $49.4 \% \mathrm{DM}$, crude lipid $0.9 \% \mathrm{DM}$; wheat meal: crude protein $16.4 \%$ DM, crude lipid 1.0\% DM (all supplied by Great Seven Biotechnology Co., Ltd). Casein: $93 \%$ crude protein and 1\% crude lipid (Alfa Aesar, Avocado Research Chemicals Ltd).

† Mineral premix (mg or g/kg diet): $\mathrm{CuSO}_{4} \cdot 5 \mathrm{H}_{2} \mathrm{O}, 10 \mathrm{mg} ; \mathrm{Na}_{2} \mathrm{SeO}_{3}(1 \%), 25 \mathrm{mg}$; $\mathrm{ZnSO}_{4} \cdot \mathrm{H}_{2} \mathrm{O}, 50 \mathrm{mg} ; \mathrm{CoCl}_{2} \cdot 6 \mathrm{H}_{2} \mathrm{O}(1 \%), 50 \mathrm{mg} ; \mathrm{MnSO}_{4} \cdot \mathrm{H}_{2} \mathrm{O}, 60 \mathrm{mg} ; \mathrm{FeSO}_{4} \cdot \mathrm{H}_{2} \mathrm{O}$, $80 \mathrm{mg} ; \mathrm{Ca}\left(\mathrm{IO}_{3}\right)_{2}, 180 \mathrm{mg} ; \mathrm{MgSO}_{4} \cdot 7 \mathrm{H}_{2} \mathrm{O}, 1200 \mathrm{mg}$; zeolite, $18.35 \mathrm{~g}$

$\ddagger$ Vitamin premix (mg or $\mathrm{g} / \mathrm{kg}$ diet): vitamin $\mathrm{D}, 5 \mathrm{mg}$; vitamin $\mathrm{K}, 10 \mathrm{mg}$; vitamin $\mathrm{B}_{12}$, $10 \mathrm{mg}$; vitamin $B_{6}, 20 \mathrm{mg}$; folic acid, $20 \mathrm{mg}$; vitamin $B_{1}, 25 \mathrm{mg}$; vitamin $A, 32 \mathrm{mg}$ vitamin $\mathrm{B}_{2}, 45 \mathrm{mg}$; pantothenic acid, $60 \mathrm{mg}$; biotin, $60 \mathrm{mg}$; niacin acid, $200 \mathrm{mg}$; $\alpha$-tocopherol, $240 \mathrm{mg}$; inositol, $800 \mathrm{mg}$; ascorbic acid, $2000 \mathrm{mg}$; microcrystalline cellulose, $16 \cdot 47 \mathrm{~g}$.

$\S$ Attractant: glycine and betaine.

|| Mold inhibitor: contained $50 \%$ calcium propionic acid and $50 \%$ fumaric acid.

If Fish oil: palmitic acid $(16: 0)$ content, $15.77 \%$ TFA; oleic acid $(18: 1 n-9)$ content, $3.29 \%$ TFA; linoleic acid $(18: 2 n-6)$ content, $2.12 \%$ TFA; linolenic acid $(18: 3 n-3)$ content, $0.42 \%$ TFA; arachidonic acid content, $0.23 \%$ TFA; EPA content, $13.34 \%$ TFA; DHA content, 10.53\% TFA (Great Seven Biotechnology Co., Ltd).

${ }^{*}$ CLA oil: palmitic acid (16: 0) content, $3.17 \%$ TFA; oleic acid (18:1n-9) content, $14.34 \%$ TFA; linoleic acid (18:2n-6) content, $2.24 \%$ TFA; $18: 2$ cis-9, trans-11 content, $38.86 \%$ TFA; 18:2 cis-10, trans-12 content, $32.91 \%$ TFA (Aohai Biotechnolgy Co., Ltd).

†† Soyabean oil: palmitic acid (16:0) content, $10.90 \%$ TFA; oleic acid $(18: 1 n-9)$ content, $16.18 \%$ TFA; linoleic acid $(18: 2 n-6)$ content, $51.22 \%$ TFA; linolenic acid $(18: 3 n-3)$ content, $6 \cdot 12 \%$ TFA (China Oil and Foodstuffs Corp.).

the experimental period, water temperature, salinity and dissolved $\mathrm{O}_{2}$ were measured daily. The water temperature ranged from 24 to $30^{\circ} \mathrm{C}$, and salinity from 32 to $36 \%$. The dissolved $\mathrm{O}_{2}$ was approximately $7 \mathrm{mg} / \mathrm{l}$.

At the termination of the experiment, fish were fasted for $24 \mathrm{~h}$ before harvest. Then, experimental fish in each cage were weighed one by one and final fish number was recorded after they were anaesthetised with eugenol as described above. After that, blood samples were obtained from the caudal vein of five fish from each cage with 27 -gauge needles and $1 \mathrm{ml}$ syringes and allowed to clot at room temperature for $4 \mathrm{~h}$ and then at $4^{\circ} \mathrm{C}$ for a further $6 \mathrm{~h}$. The clot was removed and residual blood cells were separated from the straw-coloured serum by centrifugation $\left(836 \mathrm{~g} ; 10 \mathrm{~min} ; 4^{\circ} \mathrm{C}\right)$. The serum was frozen in liquid $\mathrm{N}_{2}$ and then stored at $-80^{\circ} \mathrm{C}$ for later analysis of lysozyme activity. Livers and kidneys from five fish in each cage were pooled into $1.5 \mathrm{ml}$ tubes (RNAase-Free; Axygen), frozen in liquid $\mathrm{N}_{2}$ and then stored at $-80^{\circ} \mathrm{C}$ for later analysis of gene expression related to inflammation and fatty acid oxidation. Liver and muscle from another ten fish in each cage were pooled into $10 \mathrm{ml}$ tubes, frozen in liquid $\mathrm{N}_{2}$ and then stored at $-80^{\circ} \mathrm{C}$ for the assay of fatty acid composition, moisture and crude lipids. Whole bodies of six fish in each cage were collected into plastic bags and then stored at $-20^{\circ} \mathrm{C}$ for the assay of moisture and crude lipids.

\section{Biochemical analysis}

Crude protein was determined by digestion using the Kjeldahl method (Kjeltec FOSS 2300; Tecator) and estimated by multiplying $\mathrm{N}$ by $6 \cdot 25$. Crude lipid was measured by ether extraction using the Soxhlet method (Soxhlet Extraction System B-811). Fatty acid profiles were analysed using the procedures described by Metcalfe et al. ${ }^{(37)}$ with some modification $^{(33)}$. About $100 \mathrm{mg}$ freeze-dried samples/50 $\mu$ l oil were added into a $20 \mathrm{ml}$ volumetric screwed tube with a cover. Then $3 \mathrm{ml}$ potassium hydroxide methanol $(1 \mathrm{M})$ were added and heated in a $72^{\circ} \mathrm{C}$ water-bath for $20 \mathrm{~min}$. After that, $3 \mathrm{ml}$ hydrogen chloride methanol $(2 \mathrm{M})$ were added and the mixture was heated in a $72^{\circ} \mathrm{C}$ water-bath for another $20 \mathrm{~min}$. Previous tests were conducted to make sure that all fatty acids could be esterified following the procedures above. Finally, $1 \mathrm{ml}$ hexane was added into the mixture above, shaken vigorously for $1 \mathrm{~min}$, and then allowed to separate into two layers. Fatty acid methyl esters were separated, and quantified by a HP6890 gas chromatograph (Agilent Technologies Inc.) with a fused silica capillary column (007-CW; Hewlett Packard) and a flame ionisation detector. The column temperature was

Table 2. Fatty acid composition (\% total fatty acids) of the experimental diets with different levels of conjugated linoleic acid (CLA)*

\begin{tabular}{|c|c|c|c|c|}
\hline \multirow[b]{2}{*}{ Fatty acid } & \multicolumn{4}{|c|}{ Dietary CLA level (\%) } \\
\hline & 0 & 0.42 & 0.83 & $1 \cdot 70$ \\
\hline $14: 0$ & $2 \cdot 11$ & $2 \cdot 06$ & $2 \cdot 11$ & 1.96 \\
\hline $16: 0$ & $16 \cdot 05$ & $15 \cdot 56$ & $15 \cdot 25$ & $14 \cdot 23$ \\
\hline $18: 0$ & $4 \cdot 26$ & $4 \cdot 25$ & 4.08 & 3.92 \\
\hline $20: 0$ & 0.41 & 0.42 & 0.40 & 0.42 \\
\hline$\Sigma$ SFA & $22 \cdot 83$ & $22 \cdot 37$ & 21.84 & 20.53 \\
\hline $16: 1$ & $2 \cdot 83$ & $2 \cdot 78$ & 2.89 & 2.91 \\
\hline $18: 1$ & $22 \cdot 39$ & 21.63 & $21 \cdot 71$ & $20 \cdot 74$ \\
\hline ¿MUFA & $25 \cdot 22$ & 24.42 & 24.59 & $23 \cdot 65$ \\
\hline $18: 2 n-6$ & 37.53 & 35.07 & 33.60 & $27 \cdot 83$ \\
\hline $18: 2$ cis- 9, trans -11 & 0.00 & 1.01 & 2.49 & $5 \cdot 07$ \\
\hline $18: 2$ trans -10, cis -12 & 0.00 & 2.55 & $4 \cdot 36$ & $8 \cdot 82$ \\
\hline $20: 4 n-6$ (ARA) & $1 \cdot 78$ & 1.88 & 1.87 & 1.79 \\
\hline$\sum n-6$ PUFA & $39 \cdot 31$ & $40 \cdot 52$ & $42 \cdot 33$ & 43.51 \\
\hline $18: 3 n-3$ & 4.43 & $3 \cdot 88$ & $3 \cdot 70$ & 3.06 \\
\hline $20: 5 n-3$ (EPA) & $3 \cdot 87$ & $3 \cdot 81$ & 3.92 & 3.99 \\
\hline $22: 6 n-3(\mathrm{DHA})$ & $3 \cdot 74$ & $3 \cdot 67$ & $3 \cdot 71$ & 3.91 \\
\hline$\Sigma n-3$ PUFA & $12 \cdot 03$ & $11 \cdot 36$ & $11 \cdot 33$ & $10 \cdot 97$ \\
\hline$n-3: n-6$ PUFA & 0.30 & $0 \cdot 28$ & 0.27 & 0.25 \\
\hline n-3 HUFA & $7 \cdot 61$ & $7 \cdot 48$ & $7 \cdot 63$ & $7 \cdot 91$ \\
\hline ARA:EPA & 0.43 & 0.49 & 0.48 & 0.45 \\
\hline DHA:EPA & 0.96 & 0.96 & 0.95 & 0.98 \\
\hline CLA & 0.00 & 3.57 & $6 \cdot 86$ & $13 \cdot 89$ \\
\hline
\end{tabular}

ARA, arachidonic acid; HUFA, highly unsaturated fatty acids (EPA + DHA).

* Some fatty acids, of which the contents are minor, in trace amounts or not detected (such as $22: 0,24: 0,14: 1,20: 1 n-9,22: 1 n-11,20: 2 n-6,20: 3 n-6$ and $22: 5 n-3)$, are not listed in the Table. 
programmed to rise from $150^{\circ} \mathrm{C}$ up to $200^{\circ} \mathrm{C}$ at a rate of $15^{\circ} \mathrm{C} /$ min, and from $200^{\circ} \mathrm{C}$ to $250^{\circ} \mathrm{C}$ at a rate of $2^{\circ} \mathrm{C} / \mathrm{min}$. Injector and detector temperatures were both $250^{\circ} \mathrm{C}$.

\section{Functional immune assays}

Phagocytic index. Phagocytic index (PI) was measured according to the method of Pulsford et al. ${ }^{(38)}$ with some modification. Head kidneys of six fish per cage were removed, homogenised in the modified formula of $\mathrm{L}-15$ culture medium $(10 \mu \mathrm{g} / \mathrm{ml}$ heparin; $200 \mathrm{U} / \mathrm{ml}$ penicillin/streptomycin; 15 mM-HEPES; $1 \%$ fetal bovine serum) and then filtered through a $100 \mu \mathrm{m}$ nylon mesh. The resulting cell suspensions were enriched by centrifugation $\left(836 \mathrm{~g}, 25 \mathrm{~min}, 4^{\circ} \mathrm{C}\right)$ on a $34 \% / 51 \%$ Percoll (Pharmacia) density gradient. The cells were collected at the 34-51\% interface and washed twice using L-15 culture medium above. Then $100 \mu$ l cell suspensions were stained with $100 \mu$ l trypan blue (0.4\%; Sigma) at $23.5^{\circ} \mathrm{C}$ for $1 \mathrm{~min}$, and then detected under a microscope $(40 \times)$ to determine the cell concentration and viability. The cell viability was more than $95 \%$ and final cell concentration was adjusted to approximately $1 \times 10^{7}$ leucocytes $/ \mathrm{ml}$. Then $100 \mu \mathrm{l}$ cell suspensions of head kidney leucocytes and $100 \mu \mathrm{l}$ yeast suspension (Bakers yeast, Type II, Sigma; $1 \times 10^{8}$ cells $/ \mathrm{ml}$ ) were mixed into a $2 \mathrm{ml}$-sized plastic tube and cultured at $23.5^{\circ} \mathrm{C}$ for $40 \mathrm{~min}$. To calculate the PI, a sample of mixture was put into the blood cell counting plate (Shanghai Qiujing Biochemical Reagent and Apparatus Co., Ltd) and 200 cells were counted where the number of cells with ingested yeasts was recorded.

Respiratory burst activity. Production of intracellular superoxide anion $\left(\mathrm{O}^{2-}\right)$ for five fish from each cage was evaluated using nitroblue tetrazolium (NBT) (Sigma) reduction following the method of Secombes ${ }^{(39)}$ with some modifications. A $100 \mu \mathrm{l}$ cell suspension was stained with $100 \mu \mathrm{l}$ NBT $(1 \mathrm{mg} / \mathrm{ml}$ ) and $100 \mu \mathrm{l}$ phorbol 12-myristate 13-acetate (PMA; $1 \mu \mathrm{g} / \mathrm{ml}$; Sigma) which was used as a trigger for $\mathrm{O}^{2-}$ production for $45 \mathrm{~min}$. Absolute methanol was added to terminate the staining. Each tube was washed three times with $70 \%$ methanol and air-dried. Then, $120 \mu \mathrm{l} 2 \mathrm{M}-\mathrm{KOH}$ and $140 \mu \mathrm{l}$ dimethyl sulfoxide (DMSO) were added and absorbance was measured at $630 \mathrm{~nm}$ with a spectrophotometer using $\mathrm{KOH} / \mathrm{DMSO}$ as a blank.

Lysozyme activity. Lysozyme activity in serum was measured according to the method of Ellis ${ }^{(40)}$. Briefly, a sample of $0.05 \mathrm{ml}$ serum was added to $1.4 \mathrm{ml}$ of a suspension of Micrococcus lysodeikticus (Sigma) $(0.2 \mathrm{mg} / \mathrm{ml})$ in a $0 \cdot 1 \mathrm{~m}$-sodium phosphate buffer ( $\mathrm{pH} 6 \cdot 8$ ). The reaction was carried out at $25^{\circ} \mathrm{C}$ and absorbance was measured at $530 \mathrm{~nm}$ after 0.5 and $4.5 \mathrm{~min}$ in a spectrophotometer. Each unit is defined as the amount of sample causing a decrease in absorbance of $0 \cdot 001 / \mathrm{min}$.

Hepatic antioxidative capacity assays. Liver samples were first ground into powder in liquid $\mathrm{N}_{2}$ and then homogenised in nine volumes of ice-cold phosphate solution $(\mathrm{pH} 7.4)$ and centrifuged at $4000 \mathrm{~g}$ for $10 \mathrm{~min}$ at $4^{\circ} \mathrm{C}$. After that, the supernatant fraction was determined for soluble protein by the method of Bradford $^{(41)}$ using bovine serum albumin as standard and then stored at $-80^{\circ} \mathrm{C}$ until use.
Total antioxidative capacity. Total antioxidative capacity was assayed using a commercial kit (Nanjing Jiancheng Bio-engineering Institute). Briefly, $\mathrm{Fe}^{3+}$ can be reduced to $\mathrm{Fe}^{2+}$ under some antioxidative enzyme systems and $\mathrm{Fe}^{2+}$ can combine with phenanthroline. Absorbance was read at $520 \mathrm{~nm}$, with distilled water as blanks. Results are expressed in units of total antioxidative capacity permg soluble protein and each unit is defined as the amount of enzyme that can increase the absorbance by 0.01 in $1 \mathrm{~min}$ at $37^{\circ} \mathrm{C}$.

Catalase activity. Hepatic catalase (CAT) was assayed using a commercial kit (Nanjing Jiancheng Bio-engineering Institute). CAT reacts with $\mathrm{H}_{2} \mathrm{O}_{2}$ for exactly $1 \mathrm{~min}$ and then ammonium molybdate was quickly added to stop the reaction ${ }^{(42)}$. The remaining $\mathrm{H}_{2} \mathrm{O}_{2}$ can react with ammonium molybdate and generate a light-yellow complex. The CAT activity can be calculated by assaying the absorbance at $405 \mathrm{~nm}$, with distilled water as blanks. Results are expressed in units of CAT permg soluble protein and each unit is defined as the amount of enzyme necessary to resolve $1 \mu \mathrm{mol} \mathrm{H}_{2} \mathrm{O}_{2}$ in $1 \mathrm{~s}$ at $37^{\circ} \mathrm{C}$.

Superoxide dismutase activity. Superoxide dismutase activity was measured spectrophotochemically by the ferricytochrome $c$ method using xanthine/xanthine oxidase as the source of superoxide radicals. The reaction mixture consisted of $50 \mathrm{~mm}$-potassium phosphate buffer ( $\mathrm{pH} 7 \cdot 8$ ), 0.1 mm-EDTA, $0 \cdot 1 \mathrm{~mm}$-xanthine, $0.013 \mathrm{~mm}$-cytochrome $c$ and xanthine oxidase $(0.024 \mathrm{IU} / \mathrm{ml})$. The reaction was triggered by the addition of the xanthine oxidase. Results are expressed in units of superoxide dismutase per mg soluble protein and each unit is defined as the amount of enzyme necessary to produce $50 \%$ inhibition of the ferricytochrome $c$ reduction rate measured at $550 \mathrm{~nm}^{(43)}$.

Malondialdehyde content. Malondialdehyde (MDA) as one of the metabolites derived from lipid peroxidation was measured using the thiobarbituric acid (TBA) assay kit (Nanjing Jiancheng Bio-Engineering Institute). MDA reacts with TBA to produce a pink-coloured material that can readily be monitored by a spectrophotometer to give an overall indication of the level of lipid peroxidation ${ }^{(44)}$. Generally speaking, $100 \mu \mathrm{l}$ supernatant fraction of liver homogenates in each replicate were incubated with $20 \%$ TCA and $0.67 \% \mathrm{TBA}$ at $95^{\circ} \mathrm{C}$ for $40 \mathrm{~min}$. Absorbance was read at $532 \mathrm{~nm}$, with distilled water as blanks. Results were converted to nmol MDA per mg soluble protein using a standard sample of $10 \mathrm{nmol} / \mathrm{ml}$ malonaldehyde diethyl acetate.

\section{RNA extraction and real-time quantitative $P C R$}

Total RNA was extracted from the liver and kidneys using Trizol Reagent (Invitrogen) and electrophoresed on a $1.2 \%$ denaturing agarose gel to test the integrity. The RNA was treated with RNA-Free DNase (Takara) to remove DNA and reverse transcribed to complementary DNA (cDNA) by a PrimeScript ${ }^{\mathrm{TM}}$ RT Reagent Kit (Takara) following the instructions. First-strand cDNA was diluted by four times using sterilised double-distilled water. Real-time quantitative PCR was carried out in a quantitative thermal cycler (Mastercycler ${ }^{\circledR}$ ep realplex; Eppendorf). The amplification was performed in a total volume of $25 \mu \mathrm{l}$, containing $1 \mu \mathrm{l}$ of each primer (10 $\mu \mathrm{M})$, $1 \mu \mathrm{l}$ of the diluted first-strand cDNA product, $12.5 \mu \mathrm{l}$ of 
Table 3. Real-time quantitative PCR primers for inflammation- and fatty acid oxidation-related genes and $\beta$-actin of the large yellow croaker (Larmichthys crocea)

\begin{tabular}{|c|c|c|c|}
\hline Gene & Nucleotide sequence $\left(5^{\prime}-3^{\prime}\right)$ & Size (bp) & $\begin{array}{l}\text { GenBank reference } \\
\text { or publication }\end{array}$ \\
\hline $\operatorname{COX}-2$ & $\begin{array}{l}\text { F: ACCATCTGGCTGCGGGAAC } \\
\text { R: GAATGAGTCGTGTGGTCTGGAAG }\end{array}$ & 100 & JX520677 \\
\hline$I L-1 \beta$ & $\begin{array}{l}\text { F: AGCCAATCTGGCAAGGATCA } \\
\text { R: GCTGATGAACCAGTTGTTGT }\end{array}$ & 121 & DQ306711 \\
\hline$T N F-\alpha$ & $\begin{array}{l}\text { F: CGTCCTGGTGTTTGCTTGGT } \\
\text { R: TGTTTTCTCGGCAGTCGTCTT }\end{array}$ & 100 & Xie et al. ${ }^{(45)}$ \\
\hline PPAR $\alpha$ & $\begin{array}{l}\text { F: GTCAAGCAGATCCACGAAGCC } \\
\text { R: TGGTCTTTCCAGTGAGTATGAGCC }\end{array}$ & 82 & Zhao et al. ${ }^{(28)}$ \\
\hline CPT1 & $\begin{array}{l}\text { F: GCTGAGCCTGGTGAAGATGTTC } \\
\text { R: TCCATTTGGTTGAATTGTTTACTGTCC }\end{array}$ & 159 & JX434612 \\
\hline$A C O$ & $\begin{array}{l}\text { F: TTCTCAACGACCCAGACTTTAAGG } \\
\text { R: GTTGCCTCTGACCATATTCTTATAGC }\end{array}$ & 167 & JX456348 \\
\hline$\beta$-Actin & $\begin{array}{l}\text { F: TTATGAAGGCTATGCCCTGCC } \\
\text { R: TGAAGGAGTAGCCACGCTCTGT }\end{array}$ & 107 & Yao et al. ${ }^{(46)}$ \\
\hline
\end{tabular}

COX-2, cyclo-oxygenase-2; F, forward; R: reverse; CPT1, carnitine palmitoyl transferase I; ACO, acyl CoA oxidase.

$2 \times \mathrm{SYBR}^{\circledR}$ Premix Ex Taq ${ }^{\mathrm{TM}}$ II (Takara) and $9.5 \mu$ l of sterilised double-distilled water. The real-time PCR programme was as follows: $95^{\circ} \mathrm{C}$ for $2 \mathrm{~min}$, followed by forty cycles of $95^{\circ} \mathrm{C}$ for $10 \mathrm{~s}, 58^{\circ} \mathrm{C}$ for $10 \mathrm{~s}$, and $72^{\circ} \mathrm{C}$ for $20 \mathrm{~s}$. The primer sequence for $\beta$-actin, $C O X-2, I L-1 \beta, T N F-\alpha, P P A R \alpha, C P T 1$ and $A C O$ were designed following the published sequences for the large yellow croaker from GenBank or published papers ${ }^{(28,45,46)}$ and listed in Table 3. PCR fragments amplified by each pair of primers were sequenced, blasted and analysed to assure the specificity of each primer pair. At the end of each PCR reaction, melting curve analysis was performed to confirm that only one PCR product was present in these reactions. Standard curves were made with five different dilutions (in triplicate) of the cDNA samples and amplification efficiency was analysed according to the following equation $\mathrm{E}=10^{(-1 / \text { slope })}-1$. The primer amplification efficiency was 1.020 for $\beta$-actin, 1.004 for $C O X-2,0.9954$ for $I L-1 \beta, 1.0188$ for $T N F-\alpha, 0.9924$ for $P P A R \alpha$, 1.1190 for CPT1 and 1.0813 for $A C O$. The absolute $\Delta C_{\mathrm{T}}$ (cycle threshold) values between the target gene and inner control gene were all close to zero and indicate that the $\Delta \Delta \mathrm{C}_{\mathrm{T}}$ calculation for the relative quantification of target genes can be used. To calculate gene expression, the comparative CT method $\left(2^{-\Delta \Delta T}\right.$ method) was used as described by Yao et al. ${ }^{(46)}$.

\section{Calculations and statistical analysis}

Growth parameters were calculated as follows:

Survival rate $(\%)=100 \times($ final fish number $/$ initial fish number $)$.

Feed intake (g/kg average body weight per $\mathrm{d})$ $=$ feed consumed $(\mathrm{g}) /((\mathrm{IBW}+\mathrm{FBW}) / 2 / 1000(\mathrm{~kg})) / \mathrm{d}$.

$$
\begin{aligned}
\text { Weight gain rate }(\%)= & 100 \times((\text { final body weight } \\
- & \text { initial body weight }) / \\
& \text { initial body weight }) .
\end{aligned}
$$

Feed efficiency ratio = wet weight gain $(\mathrm{g}) /$ dry feed consumed (g).
Viserosomatic index $(\%)=100 \times($ visceral weight/body weight $)$.

Hepatosomatic index $(\%)=100 \times$ (liver weight/body weight $)$.

$$
\begin{aligned}
\text { PI }(\%)= & \text { leucocytes with ingested yeast/ } \\
& 200 \text { observed leucocytes under the microscope. }
\end{aligned}
$$

Statistical analysis was performed by using SPSS 16.0 for Windows (SPSS Inc.). All data were subjected to a one-way ANOVA and differences between the means were tested by Tukey's multiple-range test. The level of significance was set at $P<0.05$ and the results are presented as mean values with their standard errors.

\section{Results}

\section{Survival rate, growth performance and somatic indices}

Survival rate of large yellow croaker for all dietary treatments was above $91.0 \%$ and there were no significant differences among dietary treatments in the present study $(P>0.05)$. No statistical differences were detected in feed intake among dietary treatments $(19 \cdot 11-20 \cdot 74 \mathrm{~g} / \mathrm{kg}$ average body weight per d) $(P>0.05)$. As dietary CLA increased from 0 to $0.42 \%$, weight gain rate increased significantly from 499.30 to $572.52 \%$ $(P<0.01)$, and then decreased to $444.21 \%$ with dietary CLA increasing from 0.42 to $1.70 \%(P<0.05)$. No significance was detected in the feed efficiency ratio of experimental fish among dietary treatments $(P>0.05)$. The viserosomatic index of fish fed the $0.42 \%$ CLA diet $(6.79 \%)$ was significantly higher than that of fish in the control $(6.06 \%)$ and $1.70 \%$ CLA treatment $(6 \cdot 27 \%)$ groups $(P<0.05)$. Hepatosomatic index significantly increased from 1.40 to $1.93 \%$ with the increase of dietary CLA $(P<0 \cdot 05)$ (Table 4$)$.

\section{Immunological and hepatic antioxidative parameters}

As dietary CLA increased from 0 to $0.42 \%$, PI increased significantly from 17.9 to $34.7 \%$, and then decreased to $24.7 \%$ with dietary CLA increasing from 0.42 to $1.70 \%(P<0.05)$. Respiratory burst activity (value of optical density (OD) 630) showed a similar trend to PI as dietary CLA increased. Respiratory 
Table 4. Effects of dietary conjugated linoleic acid (CLA) on growth, survival and selected body parameters of large yellow croaker (Larmichthys crocea) fed soyabean oil-based diets

(Mean values with their standard errors for three determinations)

\begin{tabular}{|c|c|c|c|c|c|c|c|c|c|}
\hline & \multicolumn{8}{|c|}{ Dietary CLA level (\%) } & \multirow[b]{3}{*}{ ANOVA $P$} \\
\hline & \multicolumn{2}{|c|}{0} & \multicolumn{2}{|c|}{0.42} & \multicolumn{2}{|c|}{0.83} & \multicolumn{2}{|c|}{$1 \cdot 70$} & \\
\hline & Mean & SEM & Mean & SEM & Mean & SEM & Mean & SEM & \\
\hline IBW (g) & 7.56 & 0.60 & $7 \cdot 56$ & 0.60 & $7 \cdot 56$ & 0.60 & $7 \cdot 56$ & 0.60 & \\
\hline FBW (g) & $45 \cdot 31^{a, b}$ & 1.39 & $50 \cdot 84^{\mathrm{c}}$ & $1 \cdot 25$ & $47 \cdot 45^{\mathrm{b}, \mathrm{c}}$ & 0.08 & $41 \cdot 14^{\mathrm{a}}$ & 0.68 & 0.002 \\
\hline WGR $(\%)^{*}$ & $499 \cdot 30^{a, b}$ & $18 \cdot 42$ & $572 \cdot 52^{\mathrm{c}}$ & $16 \cdot 47$ & $527 \cdot 69^{b, c}$ & 1.03 & $444 \cdot 21^{a}$ & 9.05 & 0.002 \\
\hline $\mathrm{SR}(\%) \dagger$ & $91 \cdot 78$ & $1 \cdot 11$ & $92 \cdot 22$ & 3.64 & 96.89 & 0.56 & 95.44 & $2 \cdot 94$ & 0.133 \\
\hline $\mathrm{FI}$ (g/kg average body weight per d)‡ & $19 \cdot 63$ & 0.54 & $20 \cdot 74$ & 0.83 & $19 \cdot 50$ & $1 \cdot 22$ & $19 \cdot 11$ & 1.52 & 0.066 \\
\hline FERß & 0.95 & 0.03 & 1.03 & 0.05 & 1.06 & $0 \cdot 10$ & 1.03 & 0.04 & 0.282 \\
\hline VSII\| & $6 \cdot 06^{\mathrm{a}}$ & 0.10 & $6 \cdot 79^{\mathrm{b}}$ & 0.09 & $6 \cdot 45^{\mathrm{a}, \mathrm{b}}$ & 0.11 & $6 \cdot 27^{\mathrm{a}}$ & 0.00 & 0.014 \\
\hline HSIף & $1.40^{\mathrm{a}}$ & 0.06 & $1.74^{\mathrm{b}}$ & 0.03 & $1 \cdot 76^{\mathrm{b}}$ & 0.05 & $1.93^{b}$ & 0.09 & 0.002 \\
\hline
\end{tabular}

IBW, initial mean body weight; FBW, final mean body weight; WGR, weight gain rate; SR, survival rate; FI, feed intake; FER, feed efficiency ratio; VSI, viserosomatic index; $\mathrm{HSI}$, hepatosomatic index.

a,b,c Mean values within a row with unlike superscript letters were significantly different $(P<0.05)$.

${ }^{*}$ WGR $(\%)=100 \times((\mathrm{FBW}-\mathrm{IBW}) / \mathrm{IBW})$.

†SR $(\%)=100 \times$ final fish number/initial fish number

$\ddagger \mathrm{FI}(\mathrm{g} / \mathrm{kg}$ average body weight perd) = feed consumed $(\mathrm{g}) /((\mathrm{IBW}+\mathrm{FBW}) / 2 / 1000(\mathrm{~kg})) / \mathrm{d}$.

$\S$ FER $=$ wet weight gain $(\mathrm{g}) /$ dry feed consumed $(\mathrm{g})$

$\|$ VSI $(\%)=100 \times($ visceral weight/body weight).

ๆ HSI $(\%)=100 \times$ (liver weight/body weight).

burst activity was significantly increased by $0.83 \%$ CLA $(\mathrm{OD} 630=0 \cdot 50)$ compared with the control $(\mathrm{OD} 630=0.34)$ and $1.70 \%$ CLA treatment $(O D 630=0.42)$ groups $(P<0.05)$. However, no significant differences were observed in this parameter between the control and the $1.70 \%$ CLA groups $(P>0.05)$. There were no statistical differences in serum lysozyme activity among four dietary treatments $(P>0.05)$ (Table 5$)$.

Total antioxidative capacity increased significantly from $0 \cdot 29$ to $2 \cdot 14$ units $/ \mathrm{mg}$ protein as dietary CLA increased from 0 to $0.83 \%$, and then decreased significantly to 1.22 units/mg protein with further increase of CLA $(P<0.05)$. Hepatic CAT increased significantly from 36.46 to 71.45 units/mg protein as dietary CLA increased from 0 to $0.83 \%$, and then decreased significantly to 32.58 units/mg protein with further increase of CLA $(P<0.05)$. Superoxide dismutase activity in the liver increased from 21.68 to 29.64 units/mg protein as dietary CLA increased from 0 to $0.42 \%$ and then decreased to 18.95 units/mg protein with further increase of this fatty acid $(P>0.05)$. MDA content in the liver decreased significantly from 3.30 to $1.66 \mathrm{nmol} / \mathrm{mg}$ protein with the increase of dietary CLA $(P<0 \cdot 05)($ Table 5$)$.

\section{Proximate composition of whole body, muscle and liver}

No significant difference was detected in moisture content of the whole body, liver and muscle $(P>0.05)$. The lipid content of the whole body and muscle increased significantly with the increase of dietary CLA $(P<0.05)$. The whole body lipid content of fish fed the diets with $1.70 \%$ CLA (8.51\% wet weight) was significantly higher compared with the control (7.44\% wet weight) and $0.42 \%$ CLA treatment (7.38\% wet weight $)$ groups $(P<0.05)$. The muscle lipid content of fish fed the diets with $0.83 \%$ CLA (7.26\% wet weight) was significantly higher compared with the control (5.97\% wet weight)

Table 5. Effects of dietary conjugated linoleic acid (CLA) on selected immunological and hepatic antioxidative parameters of large yellow croaker (Larmichthys crocea) fed soyabean oil-based diets

(Mean values with their standard errors for three determinations)

\begin{tabular}{|c|c|c|c|c|c|c|c|c|c|}
\hline & \multicolumn{8}{|c|}{ Dietary CLA level (\%) } & \multirow[b]{3}{*}{ ANOVA $P$} \\
\hline & \multicolumn{2}{|c|}{0} & \multicolumn{2}{|c|}{0.42} & \multicolumn{2}{|c|}{0.83} & \multicolumn{2}{|c|}{$1 \cdot 70$} & \\
\hline & Mean & SEM & Mean & SEM & Mean & SEM & Mean & SEM & \\
\hline $\mathrm{PI}(\%)^{*}$ & $17 \cdot 9^{a}$ & 0.5 & $34 \cdot 7^{\mathrm{b}}$ & 1.7 & $33 \cdot 7^{b, c}$ & 2.4 & $24 \cdot 7^{\mathrm{a}, \mathrm{c}}$ & $2 \cdot 0$ & 0.002 \\
\hline OD630† & $0.34^{\mathrm{a}}$ & 0.02 & $0.44^{\mathrm{bc}}$ & 0.01 & $0.50^{\mathrm{c}}$ & 0.02 & $0.42^{\mathrm{a}, \mathrm{b}}$ & 0.01 & 0.001 \\
\hline Lysozyme activity (units/ml) & 137.00 & $9 \cdot 61$ & 93.50 & 4.50 & 92.50 & 1.50 & 113.50 & 5.50 & 0.550 \\
\hline T-AOC (units/mg protein) & $0.29^{a}$ & 0.06 & $1 \cdot 69^{\mathrm{b}}$ & 0.34 & $2 \cdot 14^{\mathrm{b}}$ & 0.18 & $1 \cdot 22^{\mathrm{c}}$ & 0.36 & 0.018 \\
\hline CAT (units/mg protein) & $36 \cdot 46^{a}$ & 5.52 & $45 \cdot 94^{\mathrm{a}, \mathrm{b}}$ & 2.73 & $71.45^{\mathrm{b}}$ & 7.56 & $32 \cdot 58^{a}$ & 9.58 & 0.034 \\
\hline SOD (units/mg protein) & $21 \cdot 68$ & $2 \cdot 72$ & $29 \cdot 24$ & 4.06 & $25 \cdot 66$ & 0.95 & 18.95 & 2.09 & 0.162 \\
\hline MDA (nmol/mg protein) & $3 \cdot 30^{\mathrm{a}}$ & 0.44 & $2 \cdot 80^{\mathrm{ab}}$ & 0.24 & $1.61^{\mathrm{b}}$ & 0.16 & $1.66^{b}$ & 0.18 & 0.006 \\
\hline
\end{tabular}

$\mathrm{PI}$, phagocytic index; OD, optical density; T-AOC, total antioxidative capacity; CAT, catalase; SOD, superoxide dismutase; MDA, malondialdehyde.

a,b,c Mean values within a row with unlike superscript letters were significantly different $(P<0 \cdot 05)$.

${ }^{\star} \mathrm{PI}(\%)=$ leucocytes with ingested yeast/200 observed leucocytes under the microscope.

†OD630, respiratory burst of activity. 
Table 6. Effect of dietary conjugated linoleic acid (CLA) on composition of the whole body, liver and muscle (\% of live weight) of juvenile large yellow croaker (Larmichthys crocea) fed soyabean oil-based diets

(Mean values with their standard errors for three determinations)

\begin{tabular}{|c|c|c|c|c|c|c|c|c|c|}
\hline & \multicolumn{8}{|c|}{ Dietary CLA level (\%) } & \multirow[b]{3}{*}{ ANOVA $P$} \\
\hline & \multicolumn{2}{|c|}{0} & \multicolumn{2}{|c|}{0.42} & \multicolumn{2}{|c|}{0.83} & \multicolumn{2}{|c|}{$1 \cdot 70$} & \\
\hline & Mean & SEM & Mean & SEM & Mean & SEM & Mean & SEM & \\
\hline \multicolumn{10}{|l|}{ Whole body } \\
\hline Moisture & 73.77 & 0.66 & $72 \cdot 70$ & 1.32 & 74.67 & 0.22 & 73.55 & 0.53 & 0.423 \\
\hline Lipid & $7.44^{\mathrm{a}}$ & 0.19 & $7 \cdot 38^{\mathrm{a}}$ & 0.58 & $8.25^{\mathrm{b}}$ & 0.32 & $8.51^{\mathrm{b}}$ & 0.30 & 0.011 \\
\hline \multicolumn{10}{|l|}{ Liver } \\
\hline Moisture & 64.29 & 1.27 & 61.96 & $1 \cdot 10$ & $64 \cdot 34$ & 1.41 & 62.42 & 0.48 & 0.404 \\
\hline Lipid & 19.31 & $2 \cdot 33$ & 19.53 & 1.66 & $18 \cdot 80$ & 1.56 & 19.09 & 0.38 & 0.994 \\
\hline \multicolumn{10}{|l|}{ Muscle } \\
\hline Moisture & 75.54 & 1.44 & 76.50 & 0.57 & $75 \cdot 82$ & $1 \cdot 17$ & 74.73 & 0.64 & 0.761 \\
\hline Lipid & $5.97^{a}$ & 0.04 & $5 \cdot 47^{\mathrm{a}}$ & 0.11 & $7 \cdot 26^{\mathrm{b}}$ & 0.01 & $6 \cdot 49^{a, b}$ & 0.10 & 0.035 \\
\hline
\end{tabular}

a,b Mean values within a row with unlike superscript letters were significantly different $(P<0.05)$.

and $0.42 \%$ CLA treatment $(5.47 \%$ wet weight $)$ groups $(P<0 \cdot 05)$. There were no significant differences in liver lipid concentration among dietary treatments $(P>0.05)$ (Table 6).

\section{Liver and muscle fatty acid profiles}

Deposition of CLA isomers, 18:2 cis-9, trans-11 and $18: 2$ trans-10, cis-12, were increased with the increase of dietary CLA $(P<0 \cdot 05)$. Dietary CLA modified significantly the retention of SFA, MUFA and ARA in the liver. The total percentage of SFA, mainly 14:0, 16:0 and 18:0, increased with dietary CLA increasing to $0.42 \%$, and then decreased with further increase of CLA. The hepatic concentration of $16: 0$ in the $0.83 \%$ CLA treatment group (18.97\% TFA) was significantly higher than that in the control (16.78\% TFA) and 1.70\% CLA treatment $(16.43 \%$ TFA) groups $(P<0 \cdot 05)$. Hepatic 18:0 content in the $0.42 \%$ CLA treatment group (10.64\% TFA) was significantly higher than that in the control group ( $4.92 \%$ TFA) $(P<0 \cdot 05)$. MUFA percentage in the liver decreased by a reduction in $16: 1 n-9$ and $18: 1 n-9$ as dietary CLA increased

Table 7. Fatty acid composition (\% total fatty acids) in the liver of juvenile large yellow croaker (Larmichthys crocea) fed diets with graded levels of conjugated linoleic acid $(C L A)^{*}$

(Mean values with their standard errors for three determinations)

\begin{tabular}{|c|c|c|c|c|c|c|c|c|c|}
\hline \multirow[b]{3}{*}{ Fatty acid } & \multicolumn{8}{|c|}{ Dietary CLA level (\%) } & \multirow[b]{3}{*}{ ANOVA $P$} \\
\hline & \multicolumn{2}{|c|}{0} & \multicolumn{2}{|c|}{0.42} & \multicolumn{2}{|c|}{0.83} & \multicolumn{2}{|c|}{$1 \cdot 70$} & \\
\hline & Mean & SEM & Mean & SEM & Mean & SEM & Mean & SEM & \\
\hline $14: 0$ & 1.48 & 0.01 & 1.64 & 0.02 & $1 \cdot 81$ & 0.15 & 1.67 & 0.08 & 0.213 \\
\hline $16: 0$ & $16 \cdot 78^{a}$ & 0.35 & $18 \cdot 01^{\mathrm{a}, \mathrm{b}}$ & 0.27 & $18.97^{\mathrm{b}}$ & 0.76 & $16 \cdot 43^{\mathrm{a}}$ & 0.40 & 0.020 \\
\hline $18: 0$ & $4.92^{\mathrm{a}}$ & 0.58 & $10 \cdot 64^{\mathrm{b}}$ & 1.44 & $7 \cdot 60^{a, b}$ & 1.33 & $7 \cdot 11^{\mathrm{a}, \mathrm{b}}$ & $1 \cdot 15$ & 0.047 \\
\hline $20: 0$ & $0.27^{\mathrm{a}}$ & 0.04 & $0 \cdot 18^{a, b}$ & 0.01 & $0.18^{a, b}$ & 0.05 & $0.48^{\mathrm{c}}$ & 0.04 & 0.023 \\
\hline ¿SFA & $23.59^{a}$ & 0.94 & $31 \cdot 36^{\mathrm{b}}$ & 1.54 & $29 \cdot 84^{b}$ & 2.06 & $25 \cdot 69^{a, b}$ & 1.47 & 0.041 \\
\hline $16: 1$ & $6 \cdot 93^{\mathrm{a}}$ & 0.13 & $4.08^{\mathrm{b}}$ & 0.07 & $4.00^{\mathrm{b}}$ & 0.32 & $3.90^{\mathrm{b}}$ & 0.08 & 0.000 \\
\hline $18: 1$ & $24 \cdot 88^{a}$ & $1 \cdot 17$ & $18 \cdot 65^{\mathrm{b}}$ & 0.57 & $21 \cdot 38^{a, b}$ & 1.77 & $19 \cdot 68^{b}$ & 0.17 & 0.012 \\
\hline ¿MUFA & $31 \cdot 26^{\mathrm{a}}$ & 1.72 & $22 \cdot 74^{\mathrm{b}}$ & 0.64 & $25 \cdot 62^{b}$ & 0.01 & $23.60^{\mathrm{b}}$ & 0.24 & 0.002 \\
\hline $18: 2 n-6$ & $32 \cdot 29^{a}$ & 0.72 & $31 \cdot 30^{\mathrm{a}}$ & 0.68 & $27 \cdot 01^{a, b}$ & 2.96 & $25 \cdot 97^{b}$ & 1.06 & 0.046 \\
\hline $18: 2$ cis- -9, trans -11 & $0.00^{a}$ & 0.00 & $1.01^{\mathrm{b}}$ & 0.03 & $1.54^{\mathrm{b}}$ & 0.16 & $4.52^{c}$ & 0.34 & 0.000 \\
\hline $18: 2$ trans -10, cis -12 & $0.00^{\mathrm{a}}$ & 0.00 & $1 \cdot 28^{\mathrm{b}}$ & 0.02 & $1.99^{\mathrm{b}}$ & 0.22 & $5 \cdot 60^{\mathrm{C}}$ & 0.43 & 0.000 \\
\hline $20: 4 n-6$ (ARA) & $1.64^{\mathrm{a}}$ & 0.06 & $1 \cdot 75^{a, b}$ & 0.03 & $2 \cdot 16^{\mathrm{b}}$ & 0.11 & $2 \cdot 72^{\mathrm{C}}$ & 0.15 & 0.000 \\
\hline$\Sigma n-6$ PUFA & $33.93^{a}$ & 0.74 & $34 \cdot 64^{\mathrm{a}}$ & 0.75 & $33 \cdot 24^{\mathrm{a}}$ & 1.39 & $38.91^{\mathrm{b}}$ & 1.89 & 0.039 \\
\hline $18: 3 n-3$ & 3.47 & 0.43 & $3 \cdot 26$ & 0.13 & 2.59 & 0.19 & $2 \cdot 61$ & 0.08 & 0.122 \\
\hline $20: 5 n-3$ (EPA) & 1.51 & 0.15 & 1.45 & 0.09 & 1.44 & 0.12 & 1.68 & 0.15 & 0.559 \\
\hline $22: 6 n-3(\mathrm{DHA})$ & 1.60 & 0.13 & 1.55 & 0.13 & 1.45 & 0.14 & 1.78 & 0.22 & 0.543 \\
\hline$\Sigma n-3$ PUFA & 6.59 & 0.70 & $6 \cdot 25$ & 0.34 & 5.48 & 0.27 & $6 \cdot 54$ & 0.39 & 0.349 \\
\hline$n-3: n-6$ PUFA & 0.19 & 0.02 & 0.17 & 0.01 & 0.15 & 0.01 & 0.17 & 0.02 & 0.631 \\
\hline$n-3$ HUFA & $3 \cdot 11$ & 0.28 & 2.99 & 0.21 & $2 \cdot 89$ & 0.18 & $3 \cdot 10$ & 0.00 & 0.875 \\
\hline ARA:EPA & $1 \cdot 11^{\mathrm{a}}$ & 0.12 & $1 \cdot 22^{a, b}$ & 0.06 & $1.67^{b, c}$ & 0.05 & $1.79^{c}$ & 0.11 & 0.006 \\
\hline DHA:EPA & 1.06 & 0.04 & 1.07 & 0.03 & 1.02 & 0.12 & 1.05 & 0.05 & 0.972 \\
\hline CLA & $0.00^{\mathrm{a}}$ & 0.00 & $2 \cdot 29^{b}$ & 0.05 & $3.54^{\mathrm{b}}$ & 0.37 & $10 \cdot 11^{c}$ & 0.77 & 0.000 \\
\hline
\end{tabular}

ARA, arachidonic acid; HUFA, highly unsaturated fatty acids (EPA + DHA).

$a, b, c$ Mean values within a row with unlike superscript letters were significantly different $(P<0.05)$.

* Some fatty acids, of which the contents are minor, in trace amounts or not detected (such as 22:0, 24:0, 14:1, 20:1n-9, 22:1n-11, 20:2n-6, $20: 3 n-6$ and $22: 5 n-3)$, are not listed in the Table. 
Table 8. Fatty acid composition (\% total fatty acids) in the muscle of juvenile large yellow croaker (Larmichthys crocea) fed diets with graded levels of conjugated linoleic acid (CLA)*

(Mean values with their standard errors for three determinations)

\begin{tabular}{|c|c|c|c|c|c|c|c|c|c|}
\hline \multirow[b]{3}{*}{ Fatty acid } & \multicolumn{8}{|c|}{ Dietary CLA level (\%) } & \multirow[b]{3}{*}{ ANOVA $P$} \\
\hline & \multicolumn{2}{|c|}{0} & \multicolumn{2}{|c|}{0.42} & \multicolumn{2}{|c|}{0.83} & \multicolumn{2}{|c|}{$1 \cdot 70$} & \\
\hline & Mean & SEM & Mean & SEM & Mean & SEM & Mean & SEM & \\
\hline $14: 0$ & 1.77 & 0.13 & 1.75 & 0.12 & 1.73 & 0.10 & 1.82 & 0.04 & 0.932 \\
\hline $16: 0$ & $16 \cdot 77$ & 0.57 & $17 \cdot 29$ & 0.20 & $16 \cdot 96$ & 0.06 & $16 \cdot 11$ & 0.16 & 0.132 \\
\hline $18: 0$ & $4 \cdot 64^{\mathrm{a}}$ & 0.10 & $6 \cdot 40^{a, b}$ & 0.23 & $8 \cdot 01^{b}$ & 0.60 & $6 \cdot 70^{a, b}$ & 0.28 & 0.002 \\
\hline $20: 0$ & $0.27^{a}$ & 0.01 & $0.15^{\mathrm{a}}$ & 0.02 & $0.17^{\mathrm{a}}$ & 0.03 & $0.56^{\mathrm{b}}$ & 0.08 & 0.001 \\
\hline ¿SFA & 23.45 & 0.60 & $25 \cdot 84$ & $2 \cdot 24$ & $26 \cdot 87$ & 0.53 & $25 \cdot 19$ & 0.10 & $0 \cdot 121$ \\
\hline $16: 1$ & $3.84^{a}$ & 0.16 & $3.33^{\mathrm{b}}$ & 0.07 & $3 \cdot 11^{\mathrm{b}}$ & 0.11 & $2.95^{\mathrm{b}}$ & 0.05 & 0.002 \\
\hline $18: 1$ & $22 \cdot 19^{\mathrm{a}}$ & 0.46 & $19 \cdot 84^{a, b}$ & 1.04 & $20 \cdot 27^{a, b}$ & 0.11 & $19 \cdot 11^{b}$ & 0.06 & 0.027 \\
\hline ¿MUFA & $26.03^{a}$ & 0.60 & $23 \cdot 18^{\mathrm{b}}$ & 1.03 & $23 \cdot 39^{a, b}$ & 0.14 & $22.05^{\mathrm{b}}$ & 0.10 & 0.009 \\
\hline $18: 2 n-6$ & $32 \cdot 89^{a}$ & 0.74 & $28.95^{\mathrm{b}}$ & 1.45 & $27.07^{\mathrm{b}, \mathrm{c}}$ & 0.15 & $24 \cdot 31^{c}$ & 0.29 & 0.001 \\
\hline $18: 2$ cis- 9 , trans- 11 & $0.00^{\mathrm{a}}$ & 0.00 & $1.11^{\mathrm{b}}$ & 0.03 & $2.29^{c}$ & 0.05 & $4.78^{\mathrm{d}}$ & 0.05 & 0.000 \\
\hline $18: 2$ trans -10, cis- 12 & $0.00^{\mathrm{a}}$ & 0.00 & $1.65^{\mathrm{b}}$ & 0.10 & $3.26^{\mathrm{c}}$ & 0.01 & $6 \cdot 81^{d}$ & 0.02 & 0.000 \\
\hline $20: 4 n-6$ (ARA) & $1.93^{a, b}$ & 0.07 & $1.88^{\mathrm{a}}$ & 0.03 & $2 \cdot 34^{\mathrm{b}, \mathrm{c}}$ & 0.17 & $2 \cdot 61^{\mathrm{c}}$ & 0.01 & 0.002 \\
\hline$\Sigma n-6$ PUFA & $34.82^{\mathrm{a}}$ & 0.77 & $33.37^{a}$ & 1.46 & $35 \cdot 51^{a, b}$ & 0.05 & $40 \cdot 10^{b}$ & 0.29 & 0.016 \\
\hline $18: 3 n-3$ & $3.67^{\mathrm{a}}$ & 0.08 & $3 \cdot 29^{a, b}$ & 0.13 & $3 \cdot 14^{b, c}$ & 0.02 & $2 \cdot 86^{\mathrm{c}}$ & 0.05 & 0.001 \\
\hline $20: 5 n-3$ (EPA) & 2.98 & 0.12 & 2.99 & 0.07 & 2.99 & 0.00 & 2.99 & 0.05 & 1.000 \\
\hline $22: 6 n-3(\mathrm{DHA})$ & 4.01 & 0.28 & 3.74 & 0.32 & 3.85 & 0.22 & 3.78 & 0.07 & 0.869 \\
\hline$\sum n-3$ PUFA & $10 \cdot 67$ & 0.47 & $10 \cdot 03$ & 0.42 & 9.99 & 0.23 & 9.63 & 0.17 & 0.273 \\
\hline$n-3: n-6$ PUFA & $0.31^{\mathrm{a}}$ & 0.01 & $0 \cdot 29^{a, b}$ & 0.01 & $0.28^{a, b}$ & 0.01 & $0.25^{b}$ & 0.01 & 0.022 \\
\hline$n-3$ HUFA & 6.99 & 0.39 & $6 \cdot 73$ & 0.35 & $6 \cdot 84$ & 0.22 & $6 \cdot 77$ & 0.12 & 0.921 \\
\hline ARA:EPA & $0.65^{a}$ & 0.03 & $0.63^{a}$ & 0.02 & $0.78^{a, b}$ & 0.06 & $0.87^{\mathrm{b}}$ & 0.03 & 0.004 \\
\hline DHA:EPA & 1.34 & 0.06 & 1.25 & 0.10 & 1.29 & 0.07 & 1.27 & 0.01 & 0.803 \\
\hline CLA & $0.00^{\mathrm{a}}$ & 0.00 & $2 \cdot 77^{\mathrm{b}}$ & 0.12 & $5.55^{\mathrm{C}}$ & 0.06 & $11.59^{d}$ & 0.06 & 0.000 \\
\hline
\end{tabular}

ARA, arachidonic acid; HUFA, highly unsaturated fatty acids (EPA + DHA).

$a, b, c, d$ Mean values within a row with unlike superscript letters were significantly different $(P<0.05)$

${ }^{*}$ Some fatty acids, of which the contents are minor, in trace amounts or not detected (such as $22: 0,24: 0,14: 1,20: 1 n-9,22: 1 n-11,20: 2 n-6$, $20: 3 n-6$ and $22: 5 n-3)$, are not listed in the Table.

$(P<0 \cdot 05)$. The percentage of ARA increased significantly from 1.64 to $2 \cdot 72 \%$ TFA as dietary CLA increased. The ARA:EPA ratio increased significantly from 1.11 to 2.79 with the increase in dietary CLA. There were no significant differences in the content of $n-3$ HUFA or the ratio of DHA:EPA among dietary treatments $(P>0.05)$ (Table 7$)$.

For muscle, the concentration of biologically active isomers, 18: 2 cis-9, trans-11 and 18:2 trans-10, cis-12, increased significantly with increasing dietary inclusion of CLA $(P<0.05)$. The content of SFA in muscle increased, while MUFA decreased as dietary CLA increased $(P<0 \cdot 05)$. The 18:0 content of muscle in the $0.83 \%$ CLA treatment group $(8.01 \%$ TFA) was comparable with that in the $0.42 \%$ CLA (6.40\% TFA) and $1.70 \%$ CLA (6.70\% TFA) treatment groups, but significantly higher than that in the control treatment group ( $4.64 \%$ TFA $)(P<0.05)$. ARA increased significantly from 1.93 to $2.61 \%$ TFA as dietary CLA increased. The ARA:EPA ratio increased significantly from 0.65 to 0.87 with the increase in dietary CLA. No significant differences were detected in the concentration of $n-3$ HUFA or the DHA:EPA ratio among dietary treatments $(P>0.05)$ (Table 8$)$.

\section{Expression of inflammation- and fatty acid oxidation- related genes}

The transcriptional levels of $C O X-2$ and $I L-1 \beta$ in the liver and kidney decreased significantly with increasing dietary CLA. Hepatic COX-2 mRNA expression level was significantly decreased by approximately 0.30-fold, 0.67-fold and 0.72 -fold in the $0.42,0.83$ and $1.70 \%$ CLA treatment groups, respectively $(P<0.05)$ (Fig. 1(A)). The kidney COX-2 mRNA transcriptional level was significantly decreased by about 0.60-fold, 0.70-fold and 0.85-fold in the 0.42, 0.83 and $1.70 \%$ CLA treatment groups than that in the control group, respectively $(P<0.05)$ (Fig. 1(B)). $I L-1 \beta$ mRNA levels of fish fed diets with 0.83 and $1.70 \%$ CLA were significantly decreased by about 0.90 -fold in the liver and 0.60 -fold in the kidney compared with the control group, respectively $(P<0.05)$ (Fig. 1(A) and (B)). There were no significant differences in the transcription of $T N F-\alpha$ in the liver and kidney among dietary treatments $(P>0.05)$ (Fig. 1(A) and (B)).

Hepatic PPAR $\alpha$ transcriptional levels increased significantly to the maximum levels with dietary CLA increasing from 0 to $0.42 \%$, and thereafter decreased significantly with further increase of dietary CLA $(P<0.05)$. mRNA expression levels of PPAR $\alpha$ were increased by 0.89 -fold in the $0.42 \%$ CLA treatment group while they decreased by $0 \cdot 1$-fold and $0 \cdot 4$-fold in the 0.73 and $1.70 \%$ dietary CLA treatment groups compared with the control treatment. The hepatic transcriptional levels of CPT1 in the 0.83 and $1.70 \%$ CLA treatment groups were about 1.40-fold higher than those of the control and $0.42 \%$ CLA treatment groups. The ACO transcriptional levels in the liver of fish fed diets with equal to or above $0.42 \%$ CLA were decreased by more than 0.50-fold compared with the control group (Fig. 2(A)). 
(A)

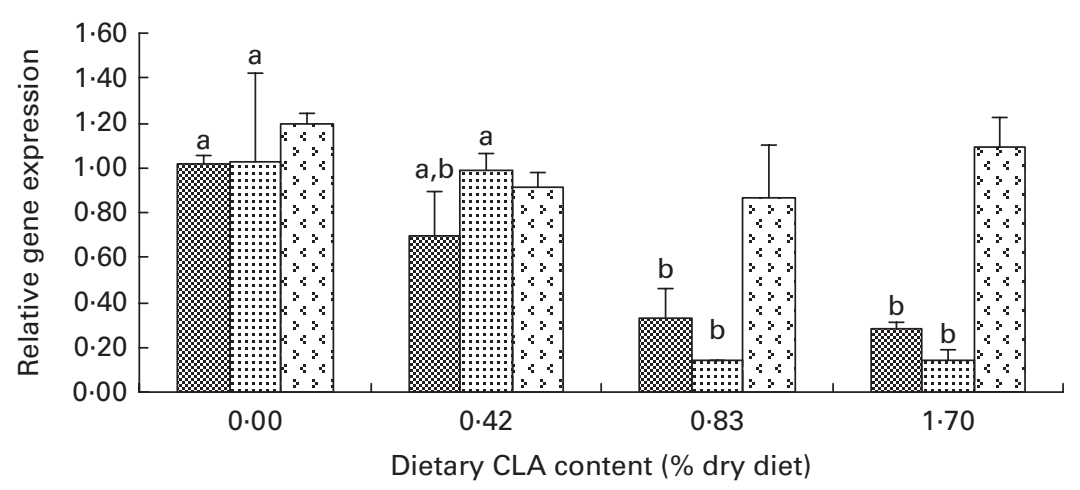

(B)

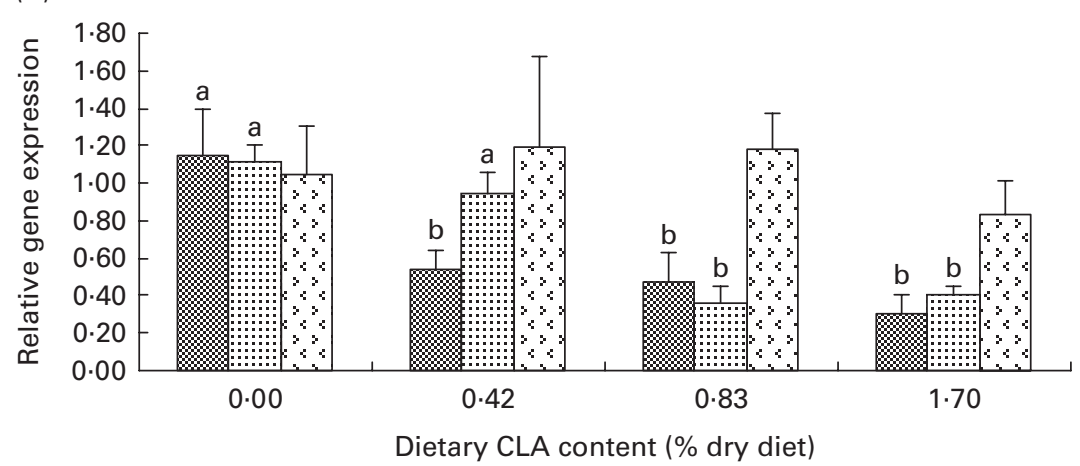

Fig. 1. Effects of dietary conjugated linoleic acid (CLA) on relative mRNA expression of inflammation-related genes (cyclo-oxygenase-2 (COX-2; 网), IL-1 $\beta$ ( $\square$ ) and $T N F-\alpha(\boxminus)$ ) in the liver (A) and kidneys (B) of juvenile large yellow croaker (Larmichthys crocea) fed soyabean oil-based diets. Values are means ( $n 3$ ), with their standard errors represented by vertical bars. ${ }^{a, b}$ Mean values for the same gene with unlike letters were significantly different $(P<0.05 ;$ Tukey's test).

There was no significant difference in kidney PPAR $\alpha$ mRNA expression among dietary treatments, though a decreasing trend was observed as dietary CLA increased $(P>0.05)$. The transcription levels of $C P T 1$ and $A C O$ in the kidney decreased significantly as dietary CLA increased. CPT1 transcriptional levels in the kidney of fish fed diets with equal to or above $0.42 \%$ CLA were significantly decreased by about 0.50 -fold compared with the control treatment group $(P<0 \cdot 05)$. ACO transcriptional levels in the kidney were decreased by 0.58-fold, 0.47 -fold and 0.63 -fold in the $0.42,0.83$ and $1.70 \%$ CLA treatment groups, respectively (Fig. 2(B)).

\section{Discussion}

In the present study, the growth of fish was significantly enhanced by moderate inclusion of CLA (0.42\%), but decreased when the level of this particular fatty acid was equal to or above $0.83 \%$. The growth-promoting effects of a moderate level of CLA are consistent with the findings in common carp ${ }^{(14)}$, Pacific white shrimp ${ }^{(47)}$ and channel catfish ${ }^{(15)}$. On the contrary, some studies have reported the deleterious effects of CLA on the growth performance of fish ${ }^{(6,8,11)}$. Thus, it can be concluded that the effect of CLA on growth performance varies significantly among different species, and this is probably due to different physiological responses to dietary CLA inclusion for different species ${ }^{(11,12)}$.

The two non-specific immune parameters, PI and respiratory burst, were significantly higher in fish fed diets with 0.42 and $0.83 \%$ CLA compared with the control and other groups. The poor non-specific immunity of fish fed the control and the highest-CLA diet $(1 \cdot 70 \%)$ could be due to a too high or low inflammation level of the fish body ${ }^{(24,25)}$. In the present study, mRNA levels of $C O X-2$ and $I L-1 \beta$ were significantly higher in the liver and kidney of fish fed the control diet with a high amount of linoleic acid $(18: 2 n-6)$. High inclusion of dietary $n-6$ fatty acids have been found to exert deleterious effects on the health of gilthead sea bream by influencing fatty acid composition of immune cells with a high deposition of linoleic acid, altering eicosanoid production, and even chronically increasing the basal expression of certain inflammationrelated genes ${ }^{(26,48-51)}$. Thus, the relatively higher level of inflammation could account for the low non-specific immunological parameters of fish fed the control diet in the present investigation. Moderate dietary CLA (0.42-0.83\%) could benefit the immunity of fish through modulating inflammation, which is characterised by transcriptional levels of $C O X-2$ and $I L-1 \beta$, to a relatively optimum level. However, cytokines are key regulators of the immune system that shape innate and adaptive immune responses ${ }^{(24)}$. Scarce expression of $\mathrm{COX}-2$ and $I L-1 \beta$ could be responsible for the relatively worse fish immunity in treatments with the higher level of CLA. Since a positive control (100\% fish oil-containing diet) was not included in the present study, it is still unknown whether dietary CLA can attenuate inflammation as strongly as fish oil does or whether dietary CLA can improve immune potential. 
(A)



(B)

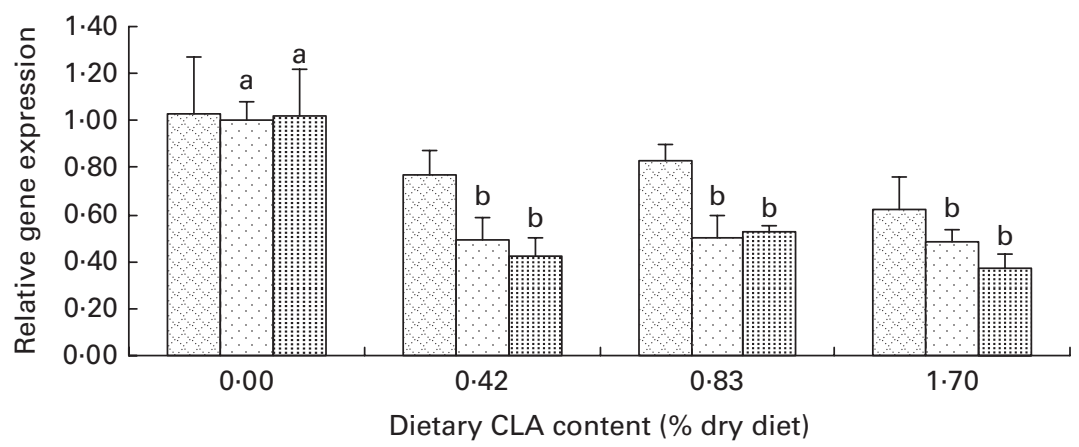

Fig. 2. Effects of dietary conjugated linoleic acid (CLA) on relative mRNA expression of fatty acid oxidation-related genes (PPAR $(\square)$, carnitine palmitoyl transferase I (CPT1; $[$ ) and acyl CoA oxidase $(A C O ;$; $)$ ) in the liver $(\mathrm{A})$ and kidneys $(\mathrm{B})$ of juvenile large yellow croaker (Larmichthys crocea) fed soyabean oil-based diets. Values are means $(n 3)$, with their standard errors represented by vertical bars. ${ }^{a, b}$ Mean values for the same gene with unlike letters were significantly different $(P<0.05$; Tukey's test).

However, it should be admitted that CLA could enhance nonspecific immunity by ameliorating high inflammation (COX-2 and IL- $1 \beta$ ) caused by high $n-6$ fatty acids at least from the results of the present study.

In the present study, no significance was detected in the transcription of $T N F-\alpha$ among dietary treatments. This was inconsistent with the findings of Montero et $a l .^{(26)}$ who found that transcription of $T N F-\alpha$ was significantly higher in fish fed diets with $100 \%$ soyabean oil compared with those fed diets with $100 \%$ fish oil, $70 \%$ linseed oil or $70 \%$ soyabean oil. However, it should be noted that transcription of $T N F-\alpha$ was detected at different time points $(1 \mathrm{~d}, 3 \mathrm{~d}$ and $7 \mathrm{~d})$ after exposure to a sub-lethal dose of Photobacterium damselae subsp. piscicida in that study. Increased expression of $T N F-\alpha$ and $I L-1 \beta$ after exposure to pathogens has been reported in several fish species ${ }^{(26,45)}$. Thus, it is possible that TNF- $\alpha$ was less sensitive than IL-1 $\beta$ to dietary CLA without pathogen challenge. Furthermore, different fish species and diet formulation could also account for the inconsistent results.

On the other hand, the immune enhancement by moderate dietary CLA may benefit from its antioxidant capacity. The antioxidant effect of CLA has been observed in many studies of rodents and human subjects ${ }^{(52-54)}$. In the present study, mRNA expression of fatty acid oxidation-related genes in the liver and kidney declined while hepatic antioxidant capacity increased as dietary CLA level increased to $0.83 \%$. This means that CLA could function as a kind of antioxidant nutrient in the large yellow croaker. Intervention with antioxidant nutrients (vitamin $\mathrm{E}$, vitamin $\mathrm{C}, \boldsymbol{\beta}$-carotene and carotenoids) has been shown to enhance the immune response in several fish species ${ }^{(31,55-59)}$. Antioxidant nutrients are proposed to exert their immune-enhancing effects through suppression of lipid peroxide and/or $\mathrm{PGE}_{2}$ production according to the findings in mammals ${ }^{(29,30)}$. In the present study, the expression of $C O X-2$ and $I L-1 \beta$ generally paralleled well with the transcription of fatty acid oxidation-related genes while showing an antagonistic tendency with hepatic antioxidant capacity as dietary CLA increased. However, hepatic antioxidant capacity was not further enhanced in fish fed the diet with the highest level of CLA, which was in accordance with PI and respiratory burst activity. Reactive oxygen species exert a critical role in bacterial killing after bacteria are ingested by phagocytes ${ }^{(60,61)}$. When fatty acid oxidation was inhibited to a very low level, the normal respiratory burst activity (reactive oxygen species production) could be unavoidably damaged.

In the present study, fish fed the control diet were subject to serious inflammation, characterised by a relatively higher transcription of $C O X-2$ and $I L-1 \beta$, higher expression of fatty acid oxidation-related genes (PPAR $\alpha, C P T-I$ and $A C O)$ and MDA production, as well as significantly lower antioxidant capacity. In accordance, the hepatosomatic index and viserosomatic index were significantly lower in fish fed the control diet. This implies that fish fed the diets without CLA (the control) may suffer hepatic injury and toxicity from serious oxidative stress and inflammation. Indeed, hepatic disease caused by inflammation and oxidative stress has been reported in 
considerable studies on rodents ${ }^{(16)}$ and male Japanese medaka $^{(27)}$. However, no direct evidence was obtained in the present study, and investigations are needed to verify this hypothesis in further studies.

An increasing lipid content of the whole body and muscle was observed as dietary CLA level increased in the present study. This could result from decreasing fatty acid oxidation, which is reflected by reduced transcription of $P P A R \alpha, C P T 1$ and $A C O$, in response to increasing dietary CLA. However, there were no significant differences in liver lipid concentration among dietary treatments. The present results are in accordance with the findings of Kennedy et $a l .^{(10)}$ who found that muscle lipid content of Atlantic salmon increased as dietary CLA increased and support the fact that dietary CLA had no significant effect on the liver lipid content of catfish $^{(7)}$, Atlantic salmon ${ }^{(10)}$ or rainbow trout juveniles ${ }^{(9)}$. In contrast, decreased lipid concentration in the whole body or liver was observed in some other studies ${ }^{(5,6,9,11)}$. The different physiological effects of CLA observed in the present study and other reports may be attributed to differences in metabolic rate, administered dose of CLA, relative proportion of each isomer in a dietary CLA mixture, or duration of the feeding period, as pointed out by Terpstra ${ }^{(62)}$. Furthermore, different diet formulations may be one important cause for the discrepancies in the effects of dietary CLA on lipid deposition. In the present investigation, soyabean oil was used to balance the total amount of oil mixture, with almost equal amount of $n-3$ HUFA and ratio of $n-3: n-6$ PUFA among the four diets. However, in most previous studies, fish oil was used to acquire equal lipid content, and thus $n-3$ HUFA and ratio of n-3:n-6 PUFA were decreased as dietary CLA increased. The lipid concentration of the whole fish body increased with the increase of dietary $n-3$ HUFA in gilthead sea bream ${ }^{(63)}$ and large yellow croaker (RT Zuo, QH Ai, KS Mai and W $\mathrm{Xu}$, unpublished results). As dietary n-3:n-6 PUFA increased, body lipid also increased in gilthead sea bream ${ }^{(64)}$ and juvenile yellow catfish ${ }^{(65)}$. Evidence above indicated that lipiddecreasing effects caused by dietary CLA could be attributed to decreased dietary $n$-3 HUFA level or $n-3: n-6$ PUFA in some previous studies.

In the present study, the total percentages of the main fatty acids were strongly affected by the dietary inclusion of CLA. A significant increase of SFA and decrease of MUFA was observed in the liver and muscle of fish fed diets with increasing amounts of CLA. This was similar to the findings of some previous studies on other fish species ${ }^{(11,66)}$. Since SFA and MUFA concentrations were equal among experimental diets in the present study, the increased SFA and decreased MUFA in the liver and muscle could be attributed to a low conversion of SFA to MUFA. Indeed, reduced activity of $\Delta 9$ desaturase, a rate-limiting enzyme converting SFA to MUFA, has been found to be suppressed by dietary CLA as pointed out by Valente et al. ${ }^{(12)}$. EPA and DHA profiles in selected tissues of the present experiment showed no significant differences among dietary treatments. This was consistent with the findings of studies by Makol et al. ${ }^{(4)}$ and Tan et al. ${ }^{(11)}$, but inconsistent with the results of some other studies where increased EPA and DHA levels were found as dietary CLA increased ${ }^{(6,12,67)}$.
Increased deposition of $n$-3 HUFA could result from a higher expression of $\Delta 5$ and $\Delta 6$ desaturases that play critical roles in HUFA biosynthesis ${ }^{(9,68)}$. In the present study, hepatic ARA concentration increased while $C O X-2$ expression decreased significantly with the increase in dietary CLA. It was possible that more ARA in the liver of fish fed the control diet participated in eicosanoid production catalysed by COX-2 and this resulted in the lower ARA deposition in the control treatment. Although $\mathrm{PGE}_{2}$ concentration was not assayed in serum or other tissues, it is usually believed that $\mathrm{PGE}_{2}$ content parallels well with $C O X-2$ transcriptional levels to a large extent ${ }^{(69-72)}$.

To conclude, a moderate level of dietary CLA could be beneficial for fish growth performance, non-specific immunity and hepatic antioxidant capacity. In the large yellow croaker, dietary CLA may exert beneficial effects through modulating the mRNA expression of inflammation-related genes $(C O X-2$ and $I L-1 \beta)$ and fatty acid oxidation-related genes (PPAR $\alpha$, $C P T 1$ and $A C O$ ). Future studies are needed to investigate the effects of this particular fatty acid on other metabolism processes such as lipid transportation and distribution in the large yellow croaker.

\section{Acknowledgements}

This research was supported by the National Natural Foundation of China (grant no. 30871930 and 31172425).

We thank H. Asino, Q. Y. Duan, J. K. Shentu, Y. W. Luo, R. J. Sun, X. W. Yi and L. Wang for their selfless help during the samplings, Y. F. Zheng for his supplying of essential facilities during the tests of immunological parameters, and $\mathrm{X}$. J. Dong for her help in cloning the core region of $A C O$.

R. Z. designed all experiments, carried out most of experimental work and wrote the manuscript under the direction of project leader Q. A.; K. M. assisted in the experimental design and manuscript revision; W. X. provided all fatty acid composition data.

There are no conflicts of interest to report.

\section{References}

1. Diez A, Menoyo D, Pérez-Benavente S, et al. (2007) Conjugated linoleic acid affects lipid composition, metabolism and gene expression in gilthead sea bream (Sparus aurata L). J Nutr 137, 1363-1369.

2. Belury M (2002) Dietary conjugated linoleic acid in health: physiological effects and mechanisms of action. Annu Rev Nutr 22, 505-531.

3. Risérus U, Smedman A, Basu S, et al. (2003) CLA and body weight regulation in humans. Lipids 38, 133-137.

4. Makol A, Torrecillas S, Fernandez-Vaquero A, et al. (2009) Effect of conjugated linoleic acid on dietary lipids utilization, liver morphology and selected immune parameters in sea bass juveniles (Dicentrarchus labrax). Comp Biochem Physiol 154B, 179-187.

5. Twibell RG, Watkins BA \& Brown PB (2001) Dietary conjugated linoleic acids and lipid source alter fatty acid composition of juvenile yellow perch, Perca flavescens. I Nutr 131, 2322-2328. 
6. Twibell RG, Watkins BA, Rogers L, et al. (2000) Effects of dietary conjugated linoleic acids on hepatic and muscle lipids in hybrid striped bass. Lipids 35, 155-161.

7. Twibell RG \& Wilson RP (2003) Effects of dietary conjugated linoleic acids and total dietary lipid concentrations on growth responses of juvenile channel catfish, Ictalurus punctatus. Aquaculture 221, 621-628.

8. Yasmin A, Takeuchi T, Hayashi M, et al. (2004) Effect of conjugated linoleic acid and docosahexanoic acids on growth of juvenile Oreochromis niloticus. Fish Sci 70, 473-481.

9. Bandarra M, Nunes ML, Andrade AM, et al. (2006) Effect of dietary conjugated linoleic acid on muscle, liver and visceral lipid deposition in rainbow trout juveniles (Oncorbynchus mykiss). Aquaculture 254, 496-505.

10. Kennedy SR, Campbell PJ, Porter A, et al. (2005) Influence of dietary conjugated linoleic acid (CLA) on lipid and fatty acid composition in liver and flesh of Atlantic salmon (Salmo salar). Comp Biochem Physiol 141, 168-178.

11. Tan XY, Luo Z, Xie P, et al. (2010) Effect of dietary conjugated linoleic acid (CLA) on growth performance, body composition and hepatic intermediary metabolism in juvenile yellow catfish Pelteobagrus fulvidraco. Aquaculture 310, 186-191.

12. Valente LMP, Bandarra NM, Figueiredo-Silva A, et al. (2007) Conjugated linoleic acid in diets for large size rainbow trout (Oncorbynchus mykiss): effects on growth, chemical composition and sensory attributes. Br J Nutr 97, 289-297.

13. Yasmin A \& Takeuchi T (2002) Influence of various dietary levels of conjugated linoleic acid (CLA) on juvenile tilapia Oreochromis niloticus. Fish Sci 68, Suppl., 991-992.

14. Choi BD, Kang SJ, Ha YL, et al. (1999) Accumulation of conjugated linoleic acid (CLA) in tissues of fish fed diets containing various levels of CLA. In Quality Attributes of Muscle Foods, pp. 61-71 [YL Xiong, CT Ho and F Shahidi, editors]. New York: Kluwer Academic/Plenum Publishers.

15. Peterson BC, Manning B \& Li M (2003) CLA-enriched diets for channel catfish. Glob Aquac Advocate 6, 48-50.

16. Byrne CD (2010) Fatty liver: role of inflammation and fatty acid nutrition. Prostaglandins Leukot Essent Fatty Acids 82, 265-271.

17. Li Y \& Watkins BA (1998) Conjugated linoleic acids alter bone fatty acid composition and reduce ex vivo prostaglandin $\mathrm{E}_{2}$ biosynthesis in rats fed $n-6$ or $n-3$ fatty acids. Lipids 33, $417-425$.

18. Kim KH \& Park HS (2003) Dietary supplementation of conjugated linoleic acid reduces colon tumor incidence in DMH-treated rats by increasing apoptosis with modulation of biomarkers. Nutrition 19, 772-777.

19. Goodwin JS \& Webb DR (1980) Regulation of the immune response by prostaglandins. Clin Immunol 15, 106-122.

20. Park Y \& Pariza MW (2007) Mechanisms of body fat modulation by conjugated linoleic acid (CLA). Food Res Int $\mathbf{4 0}$, 311-323.

21. Brown JM, Boysen MS, Chung S, et al. (2004) Conjugated linoleic acid induces human adipocyte delipidation: autocrine/paracrine regulation of MEK/ERK signaling by adipocytokines. J Biol Chem 279, 26735-26747.

22. Chung S, Brown JM, Provo JN, et al. (2005) Conjugated linoleic acid promotes human adipocyte insulin resistance through NFкB-dependent cytokine production. J Biol Chem 280, 38445-38456.

23. Wun T, McKnight H \& Tuscano JM (2004) Increased cyclooxygenase-2 (COX-2): a potential role in the pathogenesis of lymphoma. Leukemia Res 28, 179-190.

24. Chabalgoity JA, Baz A, Rial A, et al. (2007) The relevance of cytokines for development of protective immunity and rational design of vaccines. Cytokine Growth Factor Rev 18, 195-207.

25. Alfano M \& Poli G (2005) Role of cytokines and chemokines in the regulation of innate immunity and HIV infection. Mol Immunol 42, 161-182.

26. Montero D, Mathlouthi F, Tort L, et al. (2010) Replacement of dietary fish oil by vegetable oils affects humoral immunity and expression of proinflammatory cytokines genes in gilthead sea bream Sparus aurata. Fish Shellfish Immunol 29, 1073-1081.

27. Yang JH (2010) Perfluorooctanoic acid induces peroxisomal fatty acid oxidation and cytokine expression in the liver of male Japanese medaka (Oryzias latipes). Chemosphere 81, $548-552$.

28. Zhao ZY, Wu TX, Tang HG, et al. (2008) Effect of conjugated linoleic acid on growth, lipid metabolism and liver peroxisome proliferators-activated receptor expression of large yellow croaker (Pseudosciaena crocea). J Food Lipids 15, 534-554.

29. Furukawa T, Meydani SN \& Blumberg JB (1987) Reversal of age-associated decline in immune responsiveness by dietary glutathione supplementation in mice. Mech Ageing Dev $\mathbf{3 8}$, $107-117$.

30. Meydani SN, Barklund MP, Liu S, et al. (1990) Vitamin E supplementation enhances cell-mediated immunity in healthy elderly subjects. Am J Clin Nutr 52, 557-563.

31. Ai QH, Mai KS, Zhang CX, et al. (2004) Effects of dietary vitamin $\mathrm{C}$ on growth and immune response of Japanese seabass, Lateolabrax japonicus. Aquaculture 242, 489-500.

32. Ai QH, Mai KS, Zhang L, et al. (2007) Effects of dietary $\beta-1$, 3 glucan on innate immune response of large yellow croaker, Pseudosciaena crocea. Fish Shellfish Immunol 22, 394-402.

33. Ai QH, Zhao JZ, Mai KS, et al. (2008) Optimal dietary lipid level for large yellow croaker (Pseudosciaena crocea) larvae. Aquacult Nutr 14, 515-522.

34. Zhang CX, Ai QH, Mai KS, et al. (2008) Dietary lysine requirement of large yellow croaker. Pseudosciaena crocea R. Aquaculture 283, 123-127.

35. Wang J, Ai QH, Mai KS, et al. (2010) Effects of dietary ethoxyquin on growth performance and body composition of large yellow croaker Pseudosciaena crocea. Aquaculture 306, 80-84.

36. Zuo RT, Ai QH, Mai KS, et al. (2012) Effects of dietary $n-3$ highly unsaturated fatty acids on growth, nonspecific immunity, expression of some immune related genes and disease resistance of large yellow croaker (Larmichthys crocea) following natural infestation of parasites (Cryptocaryon irritans). Fish Shellfish Immunol 32, 249-258.

37. Metcalfe LD, Schmitz AA \& Pelka JR (1966) Rapid preparation of fatty acid esters from lipids for gas chromatographic analysis. Anal Chem 38, 514-515.

38. Pulsford AL, Crampe M, Langston A, et al. (1995) Modulatory effects of disease, stress, copper, TBT and vitamin E on the immune system of flatfish. Fish Shellfish Immunol 5, 631-643.

39. Secombes CJ (1990) Isolation of salmonid macrophages and analysis of their killing activity. In Techniques in Fish Immunology, pp. 137-154 [JS Stolen, TC Fletcher, DP Anderson, BS Robertsen and WB van Muiswinkel, editors]. Fair Haven, NJ: SOS Publications.

40. Ellis AE (1990) Lysozyme assays. In Techniques in Fish Immunology, pp. 101-103 [JS Stolen, TC Fletcher, DP Anderson, BS Robertsen and WB van Muiswinkel, editors]. Fair Haven, NJ: SOS Publications. 
41. Bradford M (1976) A rapid sensitive method for the quantitation of microgram quantities of protein utilizing the principle of protein-dye binding. Anal Biochem 72, 248-254.

42. Aebi H (1984) Catalase in vitro. Methods Enzymol 105, 121-127.

43. McCord JM \& Fridovich I (1969) Superoxide dismutase: an enzymatic function for erythrocuprein. J Biol Chem 244, 6049-6055.

44. Gavino VC, Miller JS, Ikharebha SO, et al. (1981) Effects of polyunsaturated fatty acids and antioxidants on lipid peroxidation in tissue cultures. J Lipid Res 22, 763-769.

45. Xie FJ, Zhang ZP, Lin P, et al. (2008) Cloning and infection response of tumour-necrosis factor $\alpha$ in large yellow croaker Pseudosciaena crocea (Richardson). J Fish Biol 73, 1149-1160.

46. Yao CL, Kong P, Wang ZY, et al. (2009) Molecular cloning and expression of MyD88 in large yellow croaker. Pseudosciaena crocea. Fish Shellfish Immunol 26, 249-255.

47. Zhong WJ, Zhang SP, Li JF, et al. (2011) Effects of dietary replacement of fish oil by conjugated linoleic acid on some meat quality traits of Pacific white shrimp Litopenaeus vannamei. Food Chem 127, 1739-1743.

48. Montero D, Kalinowski T, Obach A, et al. (2003) Vegetable lipid sources for gilthead seabream (Sparus aurata): effects on fish health. Aquaculture 225, 353-370.

49. Farndale BM, Bell JG, Bruce MP, et al. (1999) Dietary lipid composition affects blood leucocyte fatty acid compositions and plasma eicosanoid concentrations in European sea bass (Dicentrarchus labrax). Aquaculture 179, 335-350.

50. Ganga R, Bell JG, Montero D, et al. (2005) Effect of dietary lipids on plasma fatty acid profiles and prostaglandin and leptin production in gilthead seabream (Sparus aurata). Comp Biochem Physiol 142B, 410-418.

51. Montero D, Grasso V, Izquierdo MS, et al. (2008) Total substitution of fish oil by vegetable oils in gilthead sea bream (Sparus aurata) diets: effects on hepatic Mx expression and some immune parameters. Fish Shellfish Immunol 24 , $147-155$.

52. Hayek MG, Han SN, Wu DY, et al. (1999) Dietary conjugated linoleic acid influences the immune response of young and old C57BL/6NCrlBR mice. J Nutr 129, 32-38.

53. Flintoff-Dye NL \& Omaye ST (2005) Antioxidant effects of conjugated linoleic acid isomers in isolated human low-density lipoproteins. Nutr Res 25, 1-12.

54. Bergamo P, Maurano F \& Rossi M (2007) Phase 2 enzyme induction by conjugated linoleic acid improves lupusassociated oxidative stress. Free Radical Bio Med 43, 71-79.

55. Lin YH \& Shiau SY (2005) Dietary vitamin E requirement of grouper, Epinephelus malabaricus, at two lipid levels, and their effects on immune responses. Aquaculture $\mathbf{2 4 8}$, 235-244.

56. Ai QH, Mai KS, Tan BP, et al. (2006) Effects of dietary vitamin $\mathrm{C}$ on survival, growth, and immunity of large yellow croaker, Pseudosciaena crocea. Aquaculture 261, 327-336.

57. Wang ZL, Mai KS, Liufu ZG, et al. (2006) Effect of high dietary intakes of vitamin $\mathrm{E}$ and $n-3$ HUFA on immune responses and resistance to Edwardsiella tarda challenge in Japanese flounder (Paralichthys olivaceus, Temminck and Schlegel). Aquacult Res 37, 681-692.
58. Rodríguez A, Cuesta A, Esteban MÁ, et al. (2004) The effect of dietary administration of the fungus Mucor circinelloides on non-specific immune responses of gilthead seabream. Fish Shellfish Immunol 16, 241-249.

59. Amar EC, Kiron V, Akutsu T, et al. (2012) Resistance of rainbow trout Oncorhynchus mykiss to infectious hematopoietic necrosis virus (IHNV) experimental infection following ingestion of natural and synthetic carotenoids. Aquaculture 330-333, 148-155.

60. Sharp GJE, Nagelkeke LAJ \& Secombes CJ (1991) Generation of reactive oxygen species from fish macrophages and their role in the killing of fish bacterial pathogens. Dev Comp Immunol 15, 70-76.

61. Sharp GJE \& Secombes CJ (1993) The role of reactive oxygen species in the killing of the bacterial fish pathogen Aeromonas salmonicida by rainbow trout macrophages. Fish Shellfish Immunol 3, 119-129.

62. Terpstra AHM (2001) Differences between humans and mice in efficacy of the body fat lowering effect of conjugated linoleic acid: role of metabolic rate. J Nutr 131, 2067-2068.

63. Kalogeropoulos N, Alexis MN \& Henderson RJ (1992) Effects of dietary soybean and cod-liver oil levels on growth and body composition of gilthead seabream (Sparus aurata). Aquaculture 104, 293-308.

64. Robaina L, Izquierdo MS, Moyano FJ, et al. (1998) Increase of the dietary $n-3 / n-6$ fatty acid ratio and addition of phosphorus improves liver histological alterations induced by feeding diets containing soybean meal to gilthead seabream, Sparus aurata. Aquaculture 161, 281-293.

65. Tan XY, Luo Z, Xie P, et al. (2009) Effect of dietary linolenic acid/linoleic acid ratio on growth performance, hepatic fatty acid profiles and intermediary metabolism of juvenile yellow catfish Pelteobagrus fulvidraco. Aquaculture 296, 96-101.

66. Dos Santos LD, Furuya WM, da Silva LCR, et al. (2011) Dietary conjugated linoleic acid (CLA) for finishing Nile tilapia. Aquacult Nutr 17, 70-81.

67. Manning BB, Li MH, Robinson EH, et al. (2006) Enrichment of channel catfish (Ictalurus punctatus) fillets with conjugated linoleic acid and omega-3 fatty acids by dietary manipulation. Aquaculture 261, 337-342.

68. Pereira SL, Leonard AE \& Mukerji P (2003) Recent advances in the study of fatty acid desaturases from animals and lower eucaryotes. Prostaglandins Leukot Essent Fatty Acids 68, 97-106.

69. Schuligoi R, Ulcar R, Peskar BA, et al. (2003) Effect of endotoxin treatment on the expression on cyclooxygenase- 2 and prostaglandin synthesis in spinal cord dorsal root ganglia, and skin of rats. Neuroscience 116, 1043-1052.

70. Ayalasomayajula SP, Amrite AC \& Kompella UB (2004) Inhibition of cyclooxygenase-2, but not cyclooxygenase-1, reduces prostaglandin E2 secretion from diabetic rat retinas. Eur J Pharmacol 498, 275-278.

71. Candelario-Jalil E, Akundi RS, Bhatia HS, et al. (2006) Ascorbic acid enhances the inhibitory effect of aspirin on neuronal cyclooxygenase-2-mediated prostaglandin $\mathrm{E}_{2}$ production. J Neuroimmunol 174, 39-51.

72. Dhillon JK, Su XR \& Liu ZM (2010) Effects of RU486 on cyclooxygenase- 2 gene expression, prostaglandin $\mathrm{F}_{2 \alpha}$ synthesis and ovulation in Xenopus laevis. Gen Comp Endocr 165, 78-82. 